\title{
Chiral Analysis of Pesticides and Drugs of Environmental Concern: Biodegradation and Enantiomeric Fraction
}

\author{
Alexandra S. Maia ${ }^{1,2}$, Ana R. Ribeiro ${ }^{3}$, Paula M. L. Castro ${ }^{2}$ and Maria Elizabeth Tiritan ${ }^{1,4,5, *}$ \\ 1 CESPU, Instituto de Investigação e Formação Avançada em Ciências e Tecnologias da Saúde, Rua Central de \\ Gandra, 1317, 4585-116 Gandra PRD, Portugal; alexandra.a.maia@gmail.com \\ 2 Universidade Católica Portuguesa, CBQF-Centro de Biotecnologia e Química Fina-Laboratório \\ Associado, Escola Superior de Biotecnologia, Rua Arquiteto Lobão Vital, apartado 2511, 4202-401 Porto, \\ Portugal; plcastro@porto.ucp.pt \\ 3 Laboratory of Separation and Reaction Engineering - Laboratory of Catalysis and Materials (LSRE-LCM), \\ Faculdade de Engenharia, Universidade do Porto, Rua Dr. Roberto Frias s/n, 4200-465 Porto, Portugal; \\ ritalado@fe.up.pt \\ 4 Laboratório de Química Orgânica e Farmacêutica, Departamento de Ciências Químicas, Faculdade de \\ Farmácia da Universidade do Porto, Rua de Jorge Viterbo Ferreira, 228, 4050-313 Porto, Portugal \\ 5 Centro Interdisciplinar de Investigação Marinha e Ambiental (CIIMAR/CIMAR), Universidade do Porto, \\ Rua dos Bragas 289, 4050-123 Porto, Portugal \\ * Correspondence: elizabeth.tiritan@iucs.cespu.pt or tiritan@yahoo.com.br; Tel.: +351-224-157-204
}

Received: 30 August 2017; Accepted: 11 September 2017; Published: 16 September 2017

\begin{abstract}
The importance of stereochemistry for medicinal chemistry and pharmacology is well recognized and the dissimilar behavior of enantiomers is fully documented. Regarding the environment, the significance is equivalent since enantiomers of chiral organic pollutants can also differ in biodegradation processes and fate, as well as in ecotoxicity. This review comprises designed biodegradation studies of several chiral drugs and pesticides followed by enantioselective analytical methodologies to accurately measure the enantiomeric fraction (EF). The enantioselective monitoring of microcosms and laboratory-scale experiments with different environmental matrices is herein reported. Thus, this review focuses on the importance of evaluating the EF variation during biodegradation studies of chiral pharmaceuticals, drugs of abuse, and agrochemicals and has implications for the understanding of the environmental fate of chiral pollutants.
\end{abstract}

Keywords: enantiomeric fraction (EF); enantioselectivity; chiral analysis; biodegradation; pesticides; pharmaceuticals

\section{Introduction}

Chiral organic pollutants are a major trend in environmental science research and include compounds with different physical chemical properties and applications, such as pesticides, herbicides, pharmaceuticals, flame retardants, and synthetic polycyclic musk [1]. In general, agrochemicals are commercialized as racemic mixtures [2], although the bioactivity of these compounds is primarily associated with only one stereoisomer [3,4]. However, a few examples of pesticides are marketed as single enantiomeric formulations, namely some pyrethroid insecticides, aryloxypropanoate herbicides, and triazole fungicides [4]. Currently, in the pharmaceutical industry, chiral drugs are often developed and employed as single enantiomers and more enantiopure pharmaceutical preparations are being approved each year [5].

Despite the well-known importance of enantioselectivity on pharmacokinetic, pharmacodynamics, and toxicology in biological processes $[3,6,7]$, stereochemistry is often neglected in environmental 
research considering enantiomers as a unique molecular entity. However, when a racemate reaches the environment, enantiomers of the compound can differ significantly in their environmental fate as well as in their toxicological impacts; the evaluation of the enantiomeric fraction (EF) is of critical importance to assess the environmental risk of each enantiomer. Enantioselective analysis of chiral organic compounds is also important to evaluate their susceptibility to biodegradation, which can give useful insight into the biodegradative treatment to apply, as firstly proposed by Buser et al. [8]. The use of $\mathrm{EF}$ as an appropriate parameter for quantification of enantiomers in environmental analysis has been addressed [9]. Enantioselective studies on biodegradation, ecotoxicity, and environmental fate are crucial to provide an accurate risk assessment of chiral organic compounds [10-15]. Concerning the enantioselectivity of degradation processes, biotic mediums assume further relevance since biodegradation is expected to be enantioselective while abiotic degradation rates in an achiral environment are usually non-enantioselective [16-18]. Although less common, enantioselective abiotic degradation, namely in adsorption processes to sludge and soils, has been reported $[19,20]$. The EF of a chiral compound can suffer variations due to enantioselective degradation processes, and different events may contribute to these deviations: enantiomerization, racemization, or one enantiomer being preferentially degraded, leading to the enrichment of one enantiomeric form and thus accumulating in the medium [21]. The first studies on the stereoselectivity of chiral pollutants date from 1988 [22], with the first reports on the enantioselective degradation of pesticides regarding the herbicides diclofop-methyl and fenoxaprop-ethyl in soil [23], and 1999 with one of the initial studies concerning the anti-inflammatory ibuprofen in aqueous environmental matrices [8].

The most recent reviews on chiral pollutants emphasize the occurrence and toxicity of chiral pesticides and/or drugs $[5,7,18,24-26]$ and explore the importance of chirality in the environment. The purpose of this review is to focus on enantioselective biodegradation studies using environmental matrices and on the importance of chiral analysis throughout $\mathrm{EF}$ as an indicator of enantioselectivity during the degradation processes. Two types of chiral organic compounds are considered: pesticides and drugs (pharmaceuticals and drugs of abuse).

\section{Chiral Organic Pollutants in the Environment}

Pharmaceuticals are an important group of pseudo-persistent compounds that have been detected at concentrations ranging from ng L ${ }^{-1}$ to $\mu \mathrm{g} \mathrm{L}^{-1}$ in aquatic environments, causing great concern about non-target populations and, directly or indirectly, about human health via drinking water and foodborne exposure [27,28]. In 2013, the European Commission launched a Directive regulating several priority substances [29] and, more recently, a watch list of substances of environmental concern was published, including five pharmacologically active compounds (PACs): one anti-inflammatory (diclofenac), one synthetic hormone (17alpha-ethinylestradiol), and three antibiotics belonging to the macrolide class (azithromycin, clarithromycin, and erythromycin) [30].

PACs reach the environment by three main ways: the disposal of pharmaceuticals from manufacturing, hospitals, and other healthcare services; the elimination of unused pharmaceuticals through wastewater treatment plants (WWTPs) or solid waste facilities; and the excretion route after human and/or veterinary use [27]. The potential contamination of the main environmental compartments, such as surface water, ground water, and soils, which are constantly interconnected, may result in pharmaceuticals ending up in drinking water [31].

Concerning veterinary pharmaceuticals, they reach ecosystems by other pathways including treatment carried out on pets, in aquacultures, and in livestock production, with the spread of pharmaceuticals occurring directly via run-off or leaching to the ground water, or indirectly via manure use as fertilizer on agricultural soils [32,33]. In human or animal organisms, pharmaceuticals undergo metabolism, which includes chemical reactions (e.g., oxidation, reduction, hydrolysis, hydration, conjugation, condensation, or isomerization) that transform them into more hydrophilic compounds, allowing for easier excretion in urine and feces [33]. Usually, a fraction of the administered PACs is 
excreted unchanged. As such, pharmaceuticals can be excreted in the parent form, as one or several metabolites, or in both forms in varying proportions [34].

Most of the PACs and/or their metabolites resulting from human excretion reach domestic sewage, which is collected for treatment at municipal WWTPs. Since WWTPs are not designed to eliminate completely organic compounds at low concentrations [12], the WWTPs' effluents are considered the main source of human PACs in the environment and represent a critical contribution to the increasing loading of pharmaceuticals in the environment $[35,36]$. The main transformation processes of human PACs occurring within the WWTPs are sorption and biodegradation, with the latter suggested as the most important elimination process in wastewater treatment [37]. The non-biodegradable fraction and transformation products represent the "pharmaceutical bulk" of the effluent load in surface waters. For a complete understanding of the distribution and removal of each pharmaceutical in WWTPs, it is important to consider and compare both influent and effluent liquid and solid phases (i.e., sewage sludge and suspended solids) [38-40].

Additional concerns arise with chiral PACs, which represent more than half of the drugs currently in use [41]. Chiral PACs are administrated as racemates or as enantiomerically pure forms [42]. Each enantiomer can suffer metabolism, leading to other stereoisomeric compounds, or can be excreted unchanged. The study of chiral PACs in the different environmental compartments may provide valuable insight about the transport and fate of these chemicals in the environment. Although chiral PACs reach different compartments in the environment through the same pathways described for PACs in general, they have been detected in the environment with different values of EF, due to the enantioselectivity in the metabolism and/or in the biodegradation in WWTPs [43-45], as represented in Figure 1.

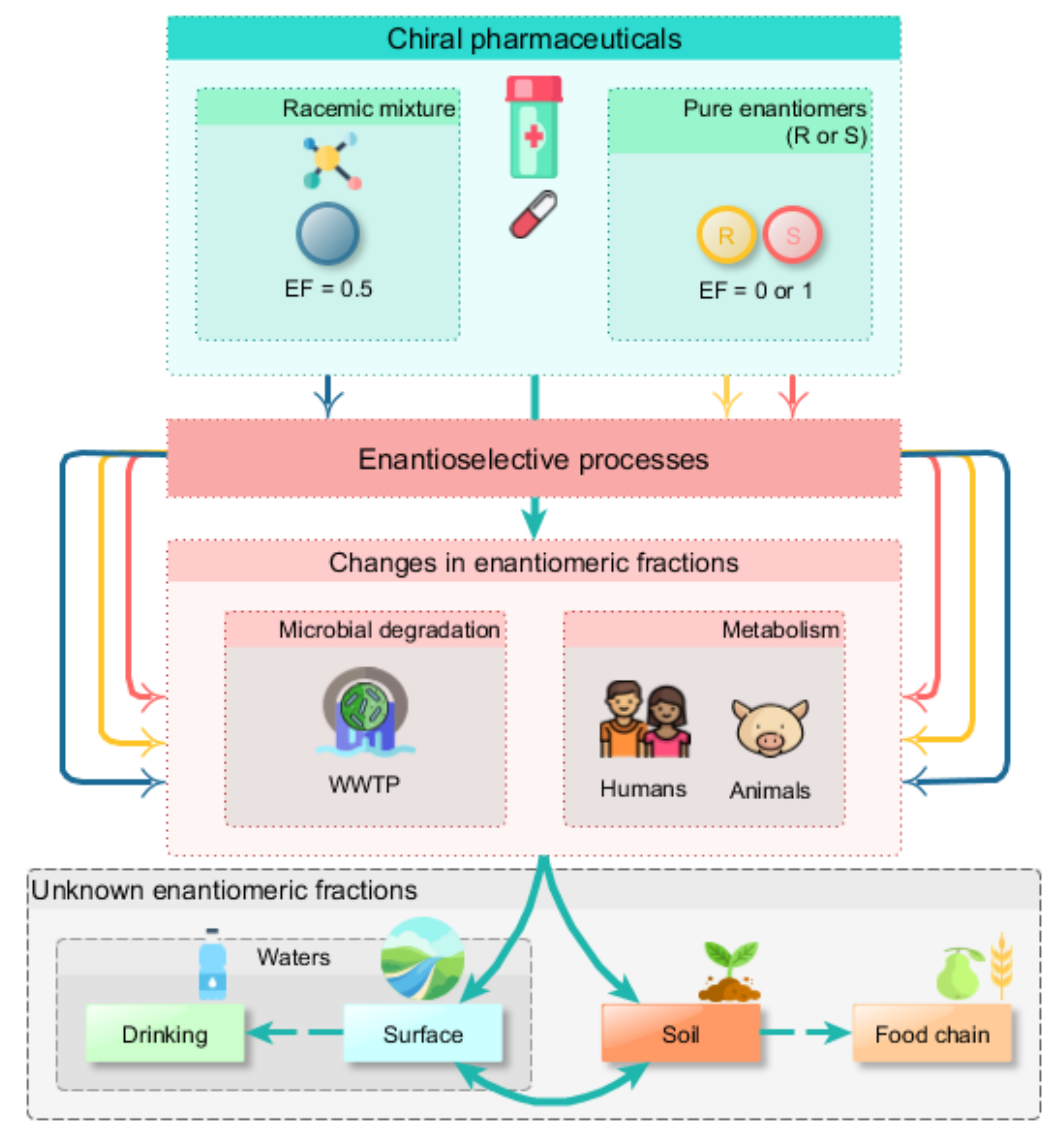

Figure 1. Representative pathways of chiral PACs in the environment. Adapted from [46]. 
Enantioselectivity has also been demonstrated in several ecotoxicological studies, regarding the survival and sublethal effects of highly ecologically relevant end points, such as growth, reproduction, and feeding rate $[47,48]$. Nevertheless, only a few therapeutic classes of chiral PACs have been reported in environmental matrices, concerning the quantification of their enantiomers [43-45,49-55]. Additionally, the biodegradation in biotic mediums, as occurs in secondary treatment of WWTPs, adds complexity to this issue since it is also expected to be enantioselective [8,56,57]. Recently, some authors have reported enantioselectivity occurring during biodegradation and a need to quantify the enantiomers in this circumstance (this point will be further discussed in Section 3).

Regarding agrochemicals, pesticides are the group of compounds that covers the largest number of substances, and can be grouped into several classes: insecticides, herbicides, fungicides, rodenticides, molluscicides, insect repellents, nematicides, and plant growth regulators [58,59]. Application of pesticides is a worldwide and of utmost importance for current agricultural productivity standards and the control of vectors and pests of public health relevance [60]. The dissipation rate of a pesticide into the environment is the primary indicator to its environmental fate [61]; these concepts are further explained in a recent review work [62]. Applied pesticides in agricultural fields affect the surrounding environmental compartments at four major levels: (i) air, through volatilization and wind action; (ii) soil, through direct application and run-off; (iii) surface waters, through run-off and via drainage systems; and (iv) ground water, via leaching and preferred water flow [62-64]. The dissipation of an applied pesticide is the predominant removal pathway and is influenced not only by its chemical characteristics but also by several environmental aspects, such as photodegradation, temperature, surface wash-off, spatial variability, humidity, and soil properties [62]. The reports on pesticides' occurrence in the environment are extensive and regard several matrices, namely soil, sediment, surface water, and ground water [65-68]. In the European Directive 2013/39/EC, the extended list of 45 priority substances included 19 pesticides [29].

Almost one-third of marketed pesticides are chiral and most of them are used as racemates even though the desirable activity is generally dependent on one unique enantiomer, while the other(s) may produce toxic or harmful effects on non-target organisms $[2,25,69,70]$. Enantioselectivity has been demonstrated in environmental fate [71], field experiments [72], toxicological studies [73], and biodegradation [74], regarding some of the most common pesticides. Works reporting enantioselective biodegradation of chiral pesticides will be further discussed in Section 4 .

\section{Biodegradation Studies of Chiral Drugs}

In the last two decades studies on biodegradation of organic pollutants have become very popular and the number of publications in this area has grown substantially. Enantioselectivity is not always considered in the studies of biodegradation of chiral compounds and most of the published works addressing it date from the year 2000 onward, as observed using specific search keywords. Since 2000 ScienceDirect ${ }^{\circledR}$ offers 193 papers related with "pharmaceuticals + enantioselective + biodegradation" out of the 269 papers related to the same keywords when no time frame was selected. In this review, studies on enantioselective biodegradation of chiral compounds will be discussed, reporting the most representative examples. EF assessment during biodegradation experiments is crucial to understanding the stereoselectivity, concerning degradative routes and elimination and/or enrichment of the target enantiomers. Biodegradation studies with pharmaceuticals and drugs of abuse are usually designed for laboratory batch incubation experiments [75-78] or laboratory-scale bioreactors [79-82]. Enantioselective studies with constructed wetlands have also been reported [83]. Table 1 shows enantioselective biodegradation studies of chiral drugs in different environmental matrices and the chiral analytical techniques used to assess the EF during degradation, published between 1999 and 2017. In the original papers [8,10,75-93], 22 different compounds from nine different drug classes are mentioned, including anti-inflammatory agents, antidepressants, and beta-blockers as the three most represented classes (Figure 2). 
Table 1. Chiral drugs discussed in this review and the chiral analytical techniques used to quantify enantiomers in biodegradation studies.

\begin{tabular}{|c|c|c|c|c|c|c|}
\hline Title & Chiral Drugs & Matrix & $\begin{array}{c}\text { Biodegradation } \\
\text { Experiment }\end{array}$ & Analytical Method & EF/Observations & Reference \\
\hline antibiotics & ofloxacin, levofloxacin & $\begin{array}{l}\text { minimal salts } \\
\text { medium inoculated } \\
\text { with activated sludge }\end{array}$ & $\begin{array}{l}\text { laboratory-scale } \\
\text { microcosms, under } \\
\text { aerobic conditions, } \\
\text { with and without an } \\
\text { extra carbon source }\end{array}$ & $\begin{array}{l}\text { HPLC-FD; } \\
\text { LC-MS/MS }\end{array}$ & $\begin{array}{l}\text { enantioselective biodegradation of } \\
\text { ofloxacin observed; }(S) \text {-ofloxacin } \\
\text { degraded at higher extents; } \\
\text { biodegradation of levofloxacin } \\
((S) \text {-enantiomer) led to }(R) \text {-enantiomer } \\
\text { formation }\end{array}$ & [77] \\
\hline anticoagulants & warfarin & $\begin{array}{l}\text { sterile and nonsterile } \\
\text { turfgrass and } \\
\text { groundcover soil }\end{array}$ & $\begin{array}{l}\text { aerobic and ambient } \\
\text { temperature } \\
\text { incubation }\end{array}$ & HPLC-FD & $\begin{array}{l}\text { fast degradation of warfarin in the } \\
\text { nonsterile soils while no degradation } \\
\text { was observed in the sterile conditions; } \\
\text { slightly enantioselective } \\
\text { biodegradation with }(R) \text {-warfarin } \\
\text { being preferentially degraded }\end{array}$ & [10] \\
\hline \multirow{4}{*}{ antidepressants } & fluoxetine & $\begin{array}{l}\text { minimal salts } \\
\text { medium inoculated } \\
\text { with a single } \\
\text { microbial strain }\end{array}$ & $\begin{array}{l}\text { batch experiment } \\
\text { incubations with an } \\
\text { additional carbon } \\
\text { source under aerobic } \\
\text { conditions, protected } \\
\text { from light }\end{array}$ & HPLC-FD & $\begin{array}{l}\text { enantioselective biodegradation of } \\
\text { fluoxetine was observed; } \\
(R) \text {-fluoxetine preferentially degraded }\end{array}$ & [89] \\
\hline & fluoxetine & synthetic wastewater & $\begin{array}{l}\text { laboratory-scale } \\
\text { aerobic granular } \\
\text { sludge sequencing } \\
\text { batch reactor }\end{array}$ & HPLC-FD & $\begin{array}{l}\text { fluoxetine degraded at low extents } \\
\text { and following a non-enantioselective } \\
\text { pattern }\end{array}$ & [80] \\
\hline & venlafaxine & river water & $\begin{array}{l}\text { laboratory-scale } \\
\text { experiments to assess } \\
\text { photolysis, sorption } \\
\text { and biodegradation }\end{array}$ & LC-MS/MS & $\begin{array}{l}\text { venlafaxine sorption and } \\
\text { biotranformation processes were } \\
\text { non-enantioselective; venlafaxine } \\
\text { biodegradation was enantioselective } \\
\text { and formed }(O) \text {-desmethylvenlafaxine }\end{array}$ & [76] \\
\hline & venlafaxine, metabolites & $\begin{array}{l}\text { WWTP effluents } \\
\text { charged with } \\
\text { activated sludge }\end{array}$ & $\begin{array}{l}\text { laboratory-scale } \\
\text { incubation of } \\
\text { effluents with } \\
\text { activated sludge } \\
\text { under anaerobic and } \\
\text { aerobic conditions }\end{array}$ & LC-MS/MS & $\begin{array}{l}\text { venlafaxine degradation presented } \\
\text { slight enantioselectivity; } \\
(O) \text {-desmethylvenlafaxine showed }(S) \\
\text { to }(R) \text {-enantiomer enrichment } \\
\text { exclusively under aerobic conditions }\end{array}$ & [75] \\
\hline
\end{tabular}


Table 1. Cont.

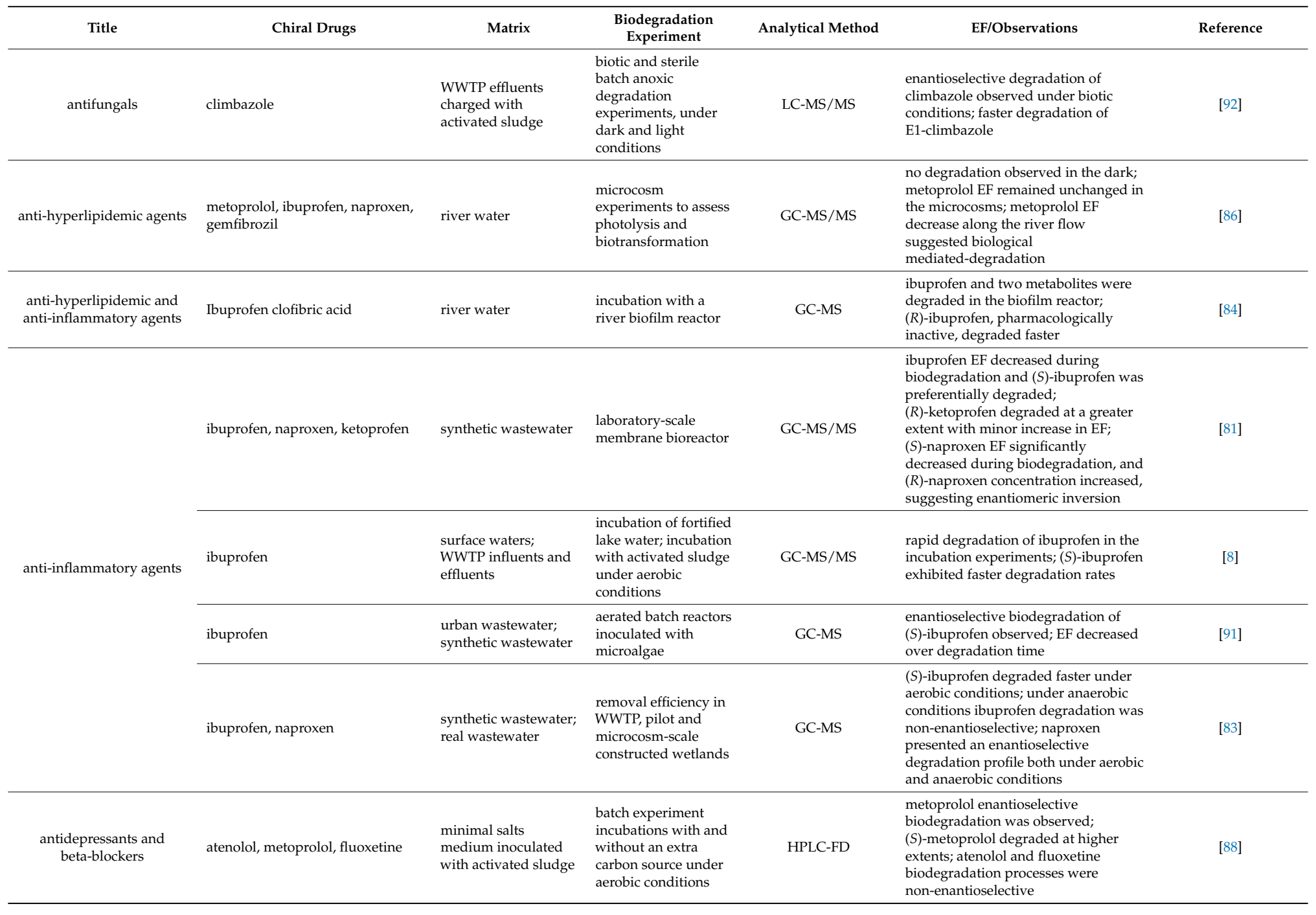


Table 1. Cont.

\begin{tabular}{|c|c|c|c|c|c|c|}
\hline Title & Chiral Drugs & Matrix & $\begin{array}{c}\text { Biodegradation } \\
\text { Experiment }\end{array}$ & Analytical Method & EF/Observations & Reference \\
\hline \multirow{2}{*}{ beta-blockers } & propranolol & $\begin{array}{l}\text { WWTP secondary } \\
\text { effluents; river water }\end{array}$ & $\begin{array}{l}\text { microcosm } \\
\text { experiments to } \\
\text { simulate } \\
\text { biotransformation in } \\
\text { WWTP (activated } \\
\text { sludge) and in surface } \\
\text { water } \\
\end{array}$ & GC-MS/MS & $\begin{array}{l}\text { EF varied in the incubation with } \\
\text { activated sludge but not in the } \\
\text { non-inoculated conditions; EF } \\
\text { remained unchanged in the surface } \\
\text { water experiments }\end{array}$ & [85] \\
\hline & alprenolol, propranolol & $\begin{array}{l}\text { minimal salts } \\
\text { medium inoculated } \\
\text { with activated sludge }\end{array}$ & $\begin{array}{l}\text { batch experiment } \\
\text { incubations with and } \\
\text { without an extra } \\
\text { carbon source under } \\
\text { aerobic conditions }\end{array}$ & HPLC-FD & $\begin{array}{l}\text { enantioselective biodegradation of } \\
\text { both drugs was observed; } \\
\text { (S)-alprenolol and (S)-propranolol } \\
\text { slightly higher degraded; } \\
\text { enantioselective degradation pattern } \\
\text { sustained in the presence of the extra } \\
\text { carbon source }\end{array}$ & [87] \\
\hline $\begin{array}{l}\text { antidepressants, } \\
\text { beta-blockers, and } \\
\text { bronchodilators }\end{array}$ & $\begin{array}{l}\text { alprenolol, bisoprolol, metoprolol, } \\
\text { propranolol, venlafaxine, } \\
\text { salbutamol, fluoxetine, } \\
\text { norfluoxetine }\end{array}$ & synthetic wastewater & $\begin{array}{l}\text { aerobic granular } \\
\text { sludge-sequencing } \\
\text { batch reactor }\end{array}$ & LC-MS/MS & $\begin{array}{l}\text { enantioselective biodegradation of } \\
\text { norfluoxetine observed; } \\
(R) \text {-norfluoxetine preferentially } \\
\text { degraded; non-enantioselective } \\
\text { removal of the other target compounds }\end{array}$ & [93] \\
\hline $\begin{array}{c}\text { antidepressants, } \\
\text { beta-blockers, } \\
\text { bronchodilators, and } \\
\text { synthetic psychoactive agents }\end{array}$ & $\begin{array}{l}\text { MDMA } \\
\text { (3,4-methylenedioxy-methamphetam } \\
\text { MDA } \\
\text { (3,4-methylenedioxyamphetamine), } \\
\text { ampethamine, methamphetamine, } \\
\text { venlafaxine, fluoxetine, } \\
\text { O-desmethylvenlafaxine, atenolol, } \\
\text { metoprololl, propranolol, } \\
\text { alprenolol, sotalol, salbutamol, } \\
\text { mirtazapine, citalopram, } \\
\text { desmethylcitalopram }\end{array}$ & $\begin{array}{l}\text { ine), } \\
\text { receiving waters } \\
\text { (mixture of river } \\
\text { water and WWTP } \\
\text { effluent); activated } \\
\text { sludge }\end{array}$ & $\begin{array}{l}\text { receiving surface } \\
\text { waters and activated } \\
\text { sludge simulating } \\
\text { microcosms systems } \\
\text { under light, dark, } \\
\text { biotic and abiotic } \\
\text { conditions }\end{array}$ & LC-MS/MS & $\begin{array}{l}\text { enantioselective degradation of } \\
\text { amphetamines, beta-blockers and } \\
\text { antidepressants observed; }(S) \text {-forms } \\
\text { preferentially degraded for } \\
\text { amphetamines and antidepressants } \\
\text { and }(R) \text {-forms for beta-blockers; } \\
\text { metabolites tested showed higher } \\
\text { enantioselective degradation rates } \\
\text { than parent compounds }\end{array}$ & [82] \\
\hline \multirow[b]{2}{*}{ synthetic psychoactive agents } & amphetamine, methamphetamine & river water & $\begin{array}{l}\text { microcosm } \\
\text { bioreactors in the } \\
\text { light (microbial } \\
\text { degradation) and in } \\
\text { the dark } \\
\text { (photochemical } \\
\text { processes) }\end{array}$ & LC-MS/MS & $\begin{array}{l}\text { EF variations observed exclusively } \\
\text { under biotic conditions; non-racemic } \\
\text { by-products formation during the } \\
\text { biodegradation }\end{array}$ & [79] \\
\hline & $\begin{array}{l}\text { amphetamine, methamphetamine, } \\
\text { MDMA, MDA }\end{array}$ & $\begin{array}{l}\text { WWTP effluents; } \\
\text { river water }\end{array}$ & $\begin{array}{l}\text { receiving surface } \\
\text { waters and activated } \\
\text { sludge simulating } \\
\text { microcosms systems }\end{array}$ & LC-MS/MS & $\begin{array}{l}\text { enantioselective biodegradation of all } \\
\text { compounds observed in activated } \\
\text { sludge simulating microcosms with } \\
\text { the }(S) \text {-enantiomers being } \\
\text { preferentially degraded; } \\
(R) \text {-enantiomers limited or } \\
\text { non-degraded; racemic MDMA } \\
\text { enantioselective biodegradation } \\
\text { resulted in }(R) \text {-enantiomer enrichment } \\
\text { and formed }(S) \text {-MDA; MDMA slight } \\
\text { enantioselective degradation observed } \\
\text { in river water }\end{array}$ & [78] \\
\hline
\end{tabular}



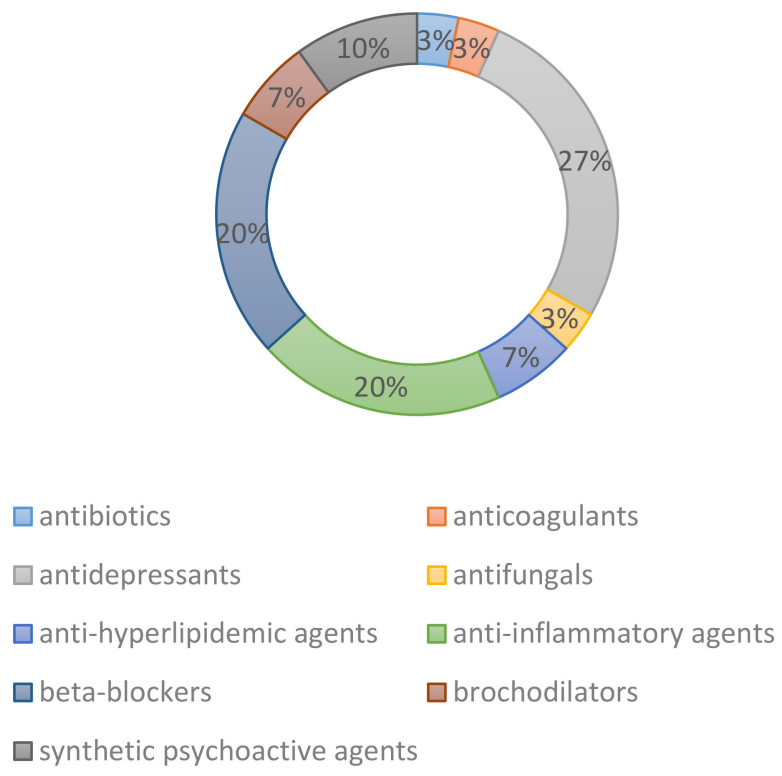

Figure 2. Relative percentages of each PAC classes mentioned in the reviewed enantioselective biodegradation studies.

Concerning the analytical methods used to quantify the enantiomers during biodegradation, a clear trend is observed. The first works used gas chromatography coupled with mass spectrometry (GC-MS) and were predominantly aimed at the enantioselective analysis of anti-inflammatory agents [8,81,83-86]. This pattern changed after 2012, when almost all works began to use liquid chromatography (LC), mostly coupled with mass spectrometry (MS) using CSP [75-79,92], a tendency that continues nowadays, with the single exception of a work published in 2009 in which GC-MS was used [91]. Regarding GC analysis, both direct and indirect methods for chiral determinations are reported. Indirect methods include a derivatization step to convert the target enantiomers in diastereomers so they can be separated through an achiral method $[81,85,86]$. Direct methods using CSP described the usage of a homemade modified beta-cyclodextrin column [8] and methyl-derivatized beta-cyclodextrin columns [83,91].

Degradation of chiral anti-inflammatory agents, specifically nonsteroidal anti-inflammatory drugs (NSAIDs), were the starting point of enantioselective biodegradation studies with pharmaceutical compounds [8,84]. Ibuprofen, ketoprofen, and naproxen biodegradation was reported in different environmental matrices as surface waters $[8,84,86]$, WWTPs influents and effluents $[8,83,91]$, and synthetic wastewater, the latter to operate a laboratory-scale bioreactor and constructed wetlands [81,83]. All the works with NSAIDs reported the use of GC-MS to perform the chiral analysis, although different methodologies are reported [8,83-86,91]. Generally enantioselective biodegradation was observed for the NSAIDs in all matrices. (S)-ibuprofen degraded faster and/or at higher extents in almost all matrices and studies $[8,81,83,91]$, except for one work with a river biofilm reactor where the pharmacologically inactive $(R)$-ibuprofen was preferentially degraded [84]. Although it has been claimed that degrading microorganisms prefer the use of the $(R)$-enantiomer, as verified by Winkler et al. [84], the majority of reports on enantioselective biodegradation of ibuprofen achieved disagreeing results, describing preferential degradation of (S)-ibuprofen. Accordingly, the influence of specific experimental settings (such as aerobic/anaerobic conditions) has been stated as preponderant in the enantioselective degradation of (S)-ibuprofen by other authors [83,94]. Naproxen presented enantioselective degradation profiles as well, with the EF decreasing under both aerobic and anaerobic conditions in WWTP treatments [83] and potential occurrence of enantiomeric inversion during a membrane bioreactor operation, where the (S)-form EF decreased over time and the $(R)$-form 
concentration increased [81]. Biodegradation of ketoprofen showed a slight preference towards the $(R)$-ketoprofen, and a slight increase of EF was observed [81].

Biodegradation assays of beta-blockers and antidepressants are herein discussed. The biodegradation of the beta-blockers alprenolol, atenolol, propranolol, and metoprolol and the antidepressant fluoxetine by an activated sludge inoculum collected from a WWTP was recently reported by our group [87,88]. Briefly, biodegradation studies of alprenolol, propranolol, and metoprolol were monitored using HPLC-FD with a vancomycin-based CSP. Biodegradation occurred in the same stereoselective pattern, with the (S)-form being degraded to a slightly higher extent. The presence of another growth substrate maintained such behavior and enhanced the biodegradation up to $14 \%$. Atenolol and fluoxetine biodegraded in a non-enantioselective way [88]. The assays were performed by supplementing the compounds into a mineral growth medium inoculated with the activated sludge inoculum, in the absence and in the presence of acetate, a ready source of carbon and energy.

As an example, chromatograms of samples supplemented with $1 \mu \mathrm{g} \mathrm{mL} \mathrm{L}^{-1}$ of alprenolol at different times are presented in Figure 3 to illustrate the degradation behavior obtained from the single supplementation.

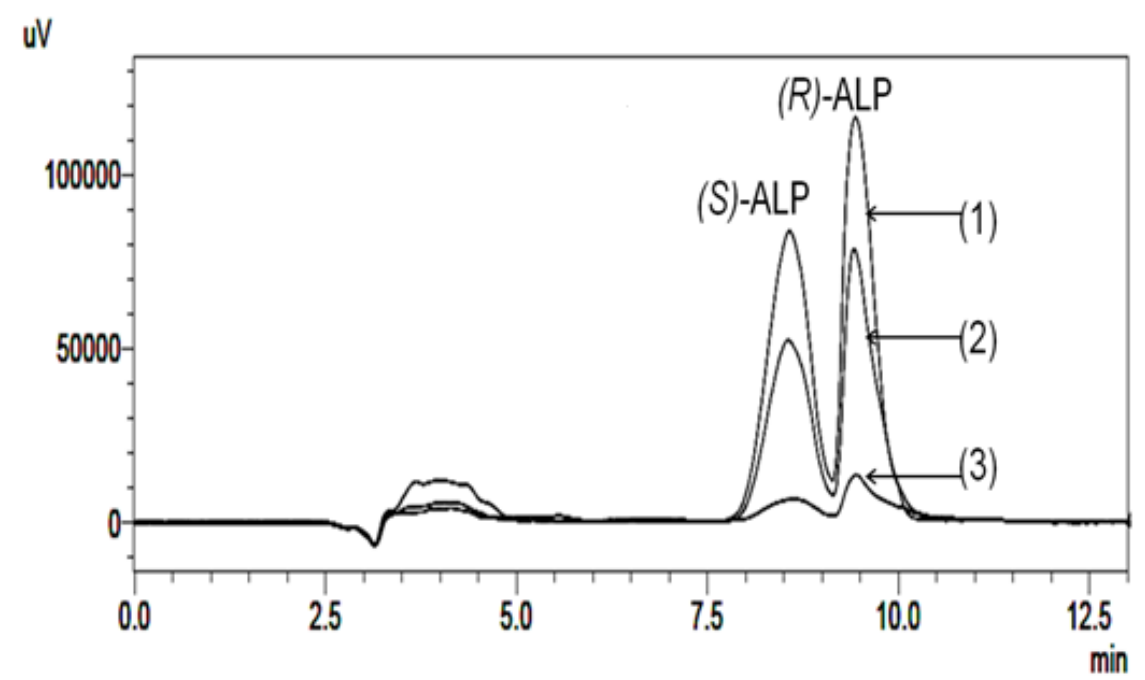

Figure 3. Representative chromatograms illustrating the loss of $(R)$ - and $(S)$-enantiomers of alprenolol (ALP) during biodegradation assays of $1 \mu \mathrm{g} \mathrm{mL}^{-1}$ solutions of a mineral growth medium containing activated sludge supplemented with acetate. The numbers represent: (1) initial time; (2) 8th day; (3) 15th day. Reproduction with permission of Elsevier (Figure 3 from Ribeiro et al. [87]).

Acetate slightly increased the biodegradation extent of all enantiomers of all beta-blockers, which may be due to a higher metabolic activity of the cells in the presence of a readily available growth substrate. For all compounds, the enantioselectivity of the degradation process in the presence of acetate was the same as that observed without this additional energy source. Activated sludge could remove both enantiomers of fluoxetine. The removal percentage was approximately $80 \%$ at an initial concentration of $1 \mu \mathrm{g} \mathrm{mL}^{-1}$ in the presence and absence of the extra carbon source. The half-life of both enantiomers was similar and biodegradation seemed to be non-enantioselective.

The biodegradation of pharmaceuticals in mixtures can be different from individual supplementation [34,51]; however, the monitoring analytical methods required separation of all enantiomers of the pool of compounds. Alprenolol and propranolol were supplemented as a mixture at two different initial concentrations $\left(0.5\right.$ and $\left.5 \mu \mathrm{g} \mathrm{mL} \mathrm{m}^{-1}\right)$, and degradation was monitored for 15 days using a validated HPLC-FD method with a vancomycin-based CSP for the simultaneous separations of the enantiomers of both compounds. Also, a mixture of metoprolol, atenolol, and fluoxetine was 
assessed in the exact same chromatographic conditions (mobile phase, column oven temperature, and flow rate). In this report, despite the similar order of magnitude of the biodegradation rate in the single and mixed supplementation, the degradation rates of the mixtures were different to that occurring during single supplementation. All enantiomers had their degradation rate diminished. It is important to assess the mixture effect, since pharmaceuticals can affect the metabolism of each other $[34,51]$. These phenomena may be explained by competition for the same enzyme and can affect biodegradation in a real environment.

The degradation of racemic-fluoxetine and its enantiomers in wastewater effluents, as well as their enantioselective degradation by L. portucalensis F11 [89], a microbial strain with the capacity to degrade a range of fluorinated aromatic compounds, was also studied and monitored with a HPLC-FD method with a vancomycin-based CSP under reversed mode of elution. This strain was used as a model organism to study the influence of stereochemistry on the biodegradation of enantiomers of fluoxetine [89]. Non-enantioselective degradation and no formation of enantiomers of the metabolite norfluoxetine were observed in the spiked wastewater samples. However, fluoxetine was degraded in an enantioselective manner by L. portucalensis F11, in assays performed with the single bacteria strain, with preferential degradation of the $(R)$-enantiomer, both at racemic and single enantiomeric supplementation [89]. The single enantiomer supplementation showed the total removal of $(R)$-fluoxetine with a slower degradation rate compared to the racemic supplementation. In the case of $(S)$-fluoxetine, almost total removal was observed with a faster degradation rate compared to the racemic supplementation. No racemization was observed [89]. This is in accordance with previous publications that enforce the dependency of the degradation pattern and the enantioselectivity on the microorganism phylogenies.

Fluoxetine is used in large amounts; however, there are only few studies concerning its biodegradation and reports on enantioselective biodegradation are rare [89,90]. A reversed-phase enantioselective LC-MS/MS method using a Chirobiotic ${ }^{\mathrm{TM}}$ V CSP was used to study the occurrence of fluoxetine in WTTP samples and revealed that the influent was more enriched in $(R)$-enantiomer than the effluent, suggesting the preferential degradation of this enantiomer in the treatment processes [95]. However, it is necessary to consider that influent and effluent samples do not necessarily represent the same plug of water and that the EF in the influent does not necessarily remain constant. This study confirmed the enantioselective biodegradation of fluoxetine by the single bacterium previously observed in our group [89], in which the (S)-enantiomer dissipation was slower than the $(R)$-enantiomer, and also reassured us that racemization phenomena were not occurring. Fluoxetine biotransformation to the metabolite norfluoxetine, which is known from human metabolism, was not detected in biodegradation by L. portucalensis F11 [89]. These results are in accordance with the abovementioned study performed in our laboratory concerning biodegradation of racemic-fluoxetine at a higher concentration of $10 \mu \mathrm{g} \mathrm{mL}^{-1}$ by activated sludge collected from a WWTP [88].

The removal of fluoxetine in a non-enantioselective manner was also recently reported in an aerobic granular sludge sequential batch reactor, suggesting adsorption of the compound to the aerobic granules [80]. This finding confirms the importance of studying not only the aqueous compartments but also the solids, such as sludge, soils, and river sediments, as reported by many authors $[45,96,97]$. A different study referred to an aerobic granular sludge-sequencing batch reactor (AGS-SBR) operated with simulated wastewater containing a mixture of chiral PACs, namely alprenolol, bisoprolol, metoprolol, propranolol, venlafaxine, salbutamol, fluoxetine, and norfluoxetine [93]. The AGS-SBR exhibited the highest removal efficiency for norfluoxetine, with preferential removal of the $(R)$-enantiomer indicating that enantioselective biologically mediated processes occurred. Removal was non-enantioselective for the other chiral PACs, and occurred through biosorption onto AGS. This study was monitored by LC-MS/MS using a Chirobiotic ${ }^{\mathrm{TM}}$ V CSP under the reverse-phase elution mode and the same analytical method developed and reported in a previous work [93]. Different works have reported the utilization of batch reactors in enantioselective biodegradation experiments with different drugs such as amphetamine, methamphetamine [79], and NSAIDs [81,84,91]. Considering 
existing reports on biodegradation experiments using batch reactors, the main strengths highlighted are the robustness of reactors' functionality, the ability to survive pollutant shock loads, and high biomass density (compared to batch incubations with bacterial consortia or activated sludge inoculum) [80,93]. Conversion of lab-scale operating reactors to full-scale reactors applied to real scenarios has been accomplished, and Portugal, the Netherlands, South Africa, and China have full-scale batch reactors currently in operation [98]. Advances in this type of technology will benefit the diffusion of its application in the future [99].

Concerning antibiotics, there are many reports regarding biodegradation $[100,101]$, but very few citations about enantioselectivity in degradation studies. In our recent work, concerning biodegradation of racemic-ofloxacin and (S)-ofloxacin (levofloxacin) by an activated sludge consortium, enantioselective degradation was observed with the (S)-enantiomer from the racemic mixture being degraded at higher extents and the degradation of the enantiopure (S)-ofloxacin leading to enrichment of the $R$-form [77]. Similar behavior was observed for the same antibiotics using the single bacterial strains L. portucalensis F11 and Rhodococcus sp. FP1, under aerobic conditions (manuscript submitted for publication). Both works were followed by LC-FD and LC-MS/MS with a Chirobiotic ${ }^{\mathrm{TM}} \mathrm{R}$ CSP under reverse-phase mode and isocratic elution, using $0.45 \%$ triethylamine aqueous solution $(\mathrm{pH} 3.6)$ and ethanol $(80 / 20, v / v)$ and ammonium formate in water (concentration $20 \mathrm{mM}, \mathrm{pH} 4.25)$ and ethanol $(80 / 20, v / v)$ as mobile phases, respectively. Reports on the enantioselective biodegradation of chiral drugs are still scarce, although there are other studies including warfarin, venlafaxine, climbazole, and synthetic psychoactive agents (amphetamine, methamphetamine, and related compounds). Macrocyclic antibiotics-based CSP, mainly Chirobiotic ${ }^{\mathrm{TM}}$ columns, are most often used in enantioselective biodegradation studies of chiral PACs [75-77,79,80,82,87-90,93], but other chiral selectors such as cyclodextrin-based [91], polysaccharide-based [92], protein-based [78,82], and Pirkle-type [10] CSP have been reported. For more information, please refer to the literature [10,11,75,76,78,79,82,92].

Different studies have considered metabolites originating during the biodegradation of chiral compounds $[75,82,84,91,93]$. Matamoros et al. followed the formation of the two major human metabolites of ibuprofen during experiments with microalgae reactors (carboxy-ibuprofen and hydroxy-ibuprofen) [91]. These metabolites, described as the most abundant originating during biodegradation, were already present at the beginning of experiments with wastewater, agreeing with occurrence data for these compounds usually found in this type of matrix [102]. Carboxy-ibuprofen and hydroxy-ibuprofen followed the degradation pattern of the parent compound, which, according to the authors, established biodegradation as the key process for their removal [91]. The formation of these metabolites was not enantioselectively monitored and analyzed. A different study with ibuprofen [84] described the detection and identification of the same two metabolites during experiments with a river biofilm reactor, as well as their degradation. The authors suggested that the degradation pathway of ibuprofen in river systems and the metabolites originated differ from those observed in human metabolism. Hydroxy-ibuprofen appears first and carboxy-ibuprofen shows more persistence in human metabolism; the opposite has been verified for the environment [84]. Amorim et al. observed enantioselective removal of norfluoxetine (metabolite of fluoxetine) in an AGS-SBR experiment and variations of the compound EF throughout the different operational phases of the reactor. Enantioselective degradation of metabolites of venlafaxine, citalopram, and MDMA was reported in two recent studies [75,82]. Degradation of the metabolite O-desmethylvenlafaxine exhibited notable enantiomeric enrichment under aerobic conditions and none under anaerobic conditions, contrary to the results obtained for the parent compound, which involved only slight stereoisomeric selectivity [75]. Evans et al. reported higher degradation extents of desmethyl metabolites of venlafaxine, citalopram, and MDMA both for stereoselective metabolic and non-stereoselective photochemical processes [82].

A recent study described beta-blockers' enantiomer adsorption by sludge using batch experiments, and reported the abiotic enantioselectivity of the processes [19]. The authors observed that the enantioselectivity of adsorption phenomena increased with the hydrophilicity of the compounds 
through variation of the EF of the beta-blockers sorbed on sludge. This work presents a new vision of the enantioselective behavior of chiral compounds in the environment, suggesting that it may not be solely associated with biologically mediated processes.

\section{Biodegradation Studies of Chiral Pesticides}

The earliest enantioselective studies on pesticides' biodegradation date back to the 1970s [103], but it was only in the 1990s that the subject began to be widely explored [13,104-115]. A research on ScienceDirect ${ }^{\circledR}$ under the keywords "pesticides + enantioselective + biodegradation" provides 267 results. This review will not cover all the works on the topic and therefore was limited to papers published after 2006, the year when a comprehensive review on environmental fate and biochemical transformations of chiral pollutants was published [1]. As previously stated regarding chiral drugs, the EF calculation during biodegradation experiments is one of the most useful tools to understand the enantioselectivity of the processes. Studies on the degradation of pesticides involving incubation tests are mostly performed in laboratory-scale batch experiments [21,116-153], with rare exceptions where the treatment performance of constructed wetlands was investigated [154].

Table 2 shows enantioselective biodegradation studies of chiral pesticides in different environmental matrices and the chiral analytical techniques used to assess the EF during degradation, published between 2006 and 2017. In the original papers [21,116-155] 41 different compounds from 14 different pesticide classes are mentioned, with triazole fungicides and phenoxy herbicides being the two most represented classes (Figure 4). Dissipation studies and field-only experiments with no incubation experiments considered were left out [72,149,156-167]. 
Table 2. Chiral pesticides discussed in this review (works published between 2006 and 2017) and the chiral analytical techniques used to quantify enantiomers in biodegradation studies.

\begin{tabular}{|c|c|c|c|c|c|}
\hline Chiral Pesticide & Matrix & Biodegradation Experiment & Analytical Method & EF/Observations & Reference \\
\hline amides & - & - & - & - & - \\
\hline beflubutamid & soil & $\begin{array}{l}\text { laboratory incubation } \\
\text { experiments under aerobic } \\
\text { conditions with acidic and } \\
\text { alkaline matrices }\end{array}$ & GC-MS & $\begin{array}{l}\text { enantioselective degradation of } \\
\text { beflubutamid observed in alkaline soil; } \\
\text { (-)-beflubutamid degraded slower in } \\
\text { alkaline soil; both enantiomers degraded } \\
\text { similarly in acidic soil; highly } \\
\text { enantioselective degradation of the } \\
\text { metabolite phenoxybutanamide observed }\end{array}$ & [116] \\
\hline aminophosphonic acid derivatives & - & - & - & - & - \\
\hline dufulin & soil & $\begin{array}{l}\text { laboratory incubation } \\
\text { experiments under sterile and } \\
\text { non-sterile conditions with } \\
\text { racemic mixture and individual } \\
\text { enantiomers }\end{array}$ & HPLC-DAD & $\begin{array}{l}\text { faster degradation of enantiopure } \\
\text { (S)-dufulin compared to its antipode; } \\
\text { enantiomerization not observed during } \\
\text { incubation of individual enantiomers }\end{array}$ & [117] \\
\hline chloroacetanilides & - & - & - & - & - \\
\hline metolachlor & soil & $\begin{array}{l}\text { laboratory incubation } \\
\text { experiments under sterile and } \\
\text { non-sterile conditions }\end{array}$ & GC-ECD & $\begin{array}{l}\text { enantioselectivity observed during } \\
\text { degradation; }(S) \text {-metolachlor degraded } \\
\text { faster than the racemic mixture }\end{array}$ & [118] \\
\hline metolachlor & runoff waters & $\begin{array}{l}\text { laboratory scale wetlands; } \\
\text { column wetlands }\end{array}$ & GC-MS & $\begin{array}{l}\text { enantioselective degradation of } \\
\text { metolachlor observed; EF variations } \\
\text { detected along the wetland distinct zones }\end{array}$ & [154] \\
\hline diphenyl ethers & - & - & - & - & - \\
\hline lactofen and metabolites & sediment & $\begin{array}{l}\text { laboratory incubation } \\
\text { experiments with racemic } \\
\text { mixture and individual } \\
\text { enantiomers }\end{array}$ & HPLC-VWD & $\begin{array}{l}\text { enantioselective degradation observed } \\
\text { with }(S) \text {-lactofen and }(S) \text {-desethyl lactofen } \\
\text { being preferentially degraded and } \\
\text { enrichment of the }(R) \text {-forms. }\end{array}$ & [119] \\
\hline imidazolinones & - & - & - & - & - \\
\hline imazethapyr & soil & $\begin{array}{l}\text { laboratory incubation } \\
\text { experiments under aerobic, } \\
\text { sterile and non-sterile conditions } \\
\text { with variable } \mathrm{pH} \text {, humidity and } \\
\text { temperature settings }\end{array}$ & HPLC-UV-CD & $\begin{array}{l}(R) \text {-imazethapyr preferentially degraded } \\
\text { in all samples; average }(R) \text {-imazethapyr } \\
\text { half-lives significantly shorter than its } \\
\text { antipode; EF values significantly higher in } \\
\text { less acidic soil }\end{array}$ & [120] \\
\hline neonicotinoids & - & - & - & - & - \\
\hline cycloxaprid & soil & $\begin{array}{l}\text { laboratory incubation } \\
\text { experiments under anoxic and } \\
\text { flooded conditions with racemic } \\
\text { mixture and individual } \\
\text { enantiomers }\end{array}$ & $\begin{array}{l}\text { HPLC-LSC; } \\
\text { LC-MS/MS }\end{array}$ & $\begin{array}{l}\text { enantioselective abiotic and biotic } \\
\text { cycloxaprid degradation not observed; } \\
\text { non-enantioselective transformation could } \\
\text { be related to the absence of oxabridged } \\
\text { ring in the transformation products }\end{array}$ & [121] \\
\hline
\end{tabular}


Table 2. Cont.

\begin{tabular}{|c|c|c|c|c|c|}
\hline Chiral Pesticide & Matrix & Biodegradation Experiment & Analytical Method & EF/Observations & Reference \\
\hline cycloxaprid & soil & $\begin{array}{l}\text { laboratory incubation } \\
\text { experiments under aerobic } \\
\text { conditions }\end{array}$ & HPLC-DAD & $\begin{array}{l}\text { non-enantioselective degradation of } \\
\text { racemic-cycloxaprid and its }(1 S 2 R) \text { - and } \\
(1 R 2 S) \text {-enantiomers observed in the soil } \\
\text { samples tested }\end{array}$ & [122] \\
\hline paichongding & soil & $\begin{array}{l}\text { laboratory incubation } \\
\text { experiments under anaerobic } \\
\text { conditions }\end{array}$ & $\begin{array}{l}\text { HPLC-DAD; } \\
\text { LC-MS/MS }\end{array}$ & $\begin{array}{l}\text { enantioselective degradation of } \\
\text { paichongding observed; types of soil } \\
\text { influenced enantiomers degradation rates; } \\
\text { degradation process originated three } \\
\text { achiral transformation products }\end{array}$ & [123] \\
\hline organochlorines & - & - & - & - & - \\
\hline $\begin{array}{c}\alpha-\mathrm{HCH}, \text { cis- and trans-chlordane, } \\
0, p^{\prime}-\mathrm{DDT}\end{array}$ & $\begin{array}{c}\text { woodland and } \\
\text { grassland background } \\
\text { soil }\end{array}$ & $\begin{array}{l}\text { laboratory incubation } \\
\text { experiments under aerobic } \\
\text { conditions }\end{array}$ & GC-ECNI-MS & $\begin{array}{l}\text { enantioselectivity degradation observed in } \\
\text { field and laboratory experiments }\end{array}$ & [124] \\
\hline organophoshorus & - & - & - & - & - \\
\hline malathion & $\begin{array}{l}\text { soil, environmental } \\
\text { waters }\end{array}$ & $\begin{array}{l}\text { laboratory incubation } \\
\text { experiments }\end{array}$ & HPLC-VWD & $\begin{array}{l}\text { (S)-malathion degraded faster than the } \\
\text { active }(R) \text {-malathion in all environmental } \\
\text { samples; biodegradation of pure } \\
\text { enantiomers of malathion showed } \\
\text { enantiomeric inversion in soil and water } \\
\text { samples }\end{array}$ & [125] \\
\hline oxadiazines & - & - & - & - & - \\
\hline indoxacarb & soil & $\begin{array}{l}\text { laboratory incubation } \\
\text { experiments under sterile and } \\
\text { non-sterile conditions with acidic } \\
\text { and alkaline matrices }\end{array}$ & HPLC-DAD & $\begin{array}{l}\text { enantioselective degradation of indoxacarb } \\
\text { observed under non-sterile conditions; } \\
(R) \text {-indoxacarb degraded faster in acidic } \\
\text { soil; (S)-indoxacarb preferentially } \\
\text { degraded in alkaline soil; } \\
\text { enantiomerization observed in both acidic } \\
\text { and alkaline soils }\end{array}$ & [126] \\
\hline phenoxies & - & - & - & - & - \\
\hline diclofop-methyl, diclofop & algae cultures & $\begin{array}{l}\text { laboratory incubation } \\
\text { experiments }\end{array}$ & HPLC-FD & $\begin{array}{l}\text { enantioselective degradation of diclofop } \\
\text { and diclofop-methyl observed and } \\
\text { influenced by temperature }\end{array}$ & [127] \\
\hline diclofop-methyl & $\begin{array}{l}\text { agricultural soil, } \\
\text { Chinese cabbage }\end{array}$ & $\begin{array}{l}\text { laboratory incubation } \\
\text { experiments; field experiments in } \\
\text { spiked plants }\end{array}$ & HPLC-DAD & $\begin{array}{l}\text { enantioselective degradation of } \\
\text { diclofop-methyl observed in two of the } \\
\text { tested soil samples, where (-)-enantiomer } \\
\text { degraded faster; (+)-enantiomer } \\
\text { preferentially degraded in cabbage }\end{array}$ & [128] \\
\hline dichlorprop-methyl & sediment & $\begin{array}{l}\text { laboratory incubation } \\
\text { experiments with bacterial strain } \\
\text { isolated from activated sludge }\end{array}$ & $\begin{array}{l}\text { HPLC-UV-CD; } \\
\text { GC-ECD }\end{array}$ & $\begin{array}{l}(R) \text {-dichlorprop-methyl preferentially } \\
\text { degraded at different } \mathrm{pH} \text { values; } \\
\text { enantioselectivity more evident at neutral } \\
\text { pH conditions }\end{array}$ & [129] \\
\hline
\end{tabular}


Table 2. Cont

\begin{tabular}{|c|c|c|c|c|c|}
\hline Chiral Pesticide & Matrix & Biodegradation Experiment & Analytical Method & EF/Observations & Reference \\
\hline fluazifop-butyl & soil, water & $\begin{array}{l}\text { laboratory incubation } \\
\text { experiments under different } \mathrm{pH} \\
\text { conditions (water) with racemic } \\
\text { mixture and individual } \\
\text { enantiomers }\end{array}$ & LC-MS/MS & $\begin{array}{l}\text { enantioselective degradation of } \\
\text { fluazifop-butyl observed in two soil } \\
\text { samples but not on water; enantiomeric } \\
\text { form preferentially degraded varied } \\
\text { within soil samples }\end{array}$ & [130] \\
\hline mecoprop & $\begin{array}{l}\text { soil sampled at } \\
\text { different depths }\end{array}$ & $\begin{array}{l}\text { laboratory incubation } \\
\text { experiments under aerobic and } \\
\text { anaerobic conditions }\end{array}$ & LC-MS/MS & $\begin{array}{l}(R) \text {-mecoprop preferentially degraded } \\
\text { under aerobic conditions in soils from } 3 \\
\text { and } 6 \mathrm{~m} \text { depth when using nM mecoprop } \\
\text { concentrations; }(S) \text {-mecoprop } \\
\text { preferentially degraded in all samples } \\
\text { when using higher mecoprop } \\
\text { concentrations }(\mu \mathrm{M})\end{array}$ & [131] \\
\hline $\begin{array}{c}\text { quizalofop-ethyl, } \\
\text { quizalofop-acid (metabolite) }\end{array}$ & soil & $\begin{array}{l}\text { laboratory incubation } \\
\text { experiments with racemic } \\
\text { mixture and individual } \\
\text { enantiomers }\end{array}$ & HPLC-UV & $\begin{array}{l}\text { enantioselective degradation of } \\
\text { quizalofop-ethyl observed; } \\
\text { (S)-quizalofop-ethyl degraded faster both } \\
\text { in acidic and alkaline soils; quizalofop-acid } \\
\text { degraded faster in acidic soil; } \\
\text { quizalofop-acid enantiomerization } \\
\text { observed with enrichment of the } \\
(R) \text {-enantiomer }\end{array}$ & [132] \\
\hline spiroxamine & soil & $\begin{array}{l}\text { laboratory incubation } \\
\text { experiments under anaerobic } \\
\text { conditions }\end{array}$ & LC-MS; GC-MS & $\begin{array}{l}\text { non-enantioselective degradation of } \\
\text { spiroxamine observed }\end{array}$ & [133] \\
\hline phenylamides & - & - & - & - & - \\
\hline benalaxyl & $\begin{array}{l}\text { agricultural soil, } \\
\text { cucumber plant }\end{array}$ & $\begin{array}{l}\text { laboratory incubation } \\
\text { experiments in the dark }\end{array}$ & HPLC-DAD & $\begin{array}{l}\text { enantioselective degradation of benalaxyl } \\
\text { observed; }(S) \text {-benalaxyl degraded faster in } \\
\text { plants and }(R) \text {-benalaxyl degraded faster } \\
\text { in soils }\end{array}$ & [134] \\
\hline benalaxyl & soil, vegetables & $\begin{array}{l}\text { laboratory incubation } \\
\text { experiments with soil; growth of } \\
\text { plants in controlled environment } \\
\text { with fungicide application }\end{array}$ & HPLC-DAD & $\begin{array}{l}\text { enantioselective degradation observed in } \\
\text { soil where }(R) \text {-benalaxyl dissipated faster; } \\
(S) \text {-benalaxyl preferentially degraded in all } \\
\text { vegetables with resulting enrichment of } \\
(R) \text {-benalaxyl. }\end{array}$ & [135] \\
\hline benalaxyl & $\begin{array}{l}\text { freshwater algae } \\
\text { cultures }\end{array}$ & $\begin{array}{l}\text { laboratory incubation } \\
\text { experiments }\end{array}$ & HPLC-UV & $\begin{array}{l}\text { enantioselective degradation of benalaxyl } \\
\text { observed; (S)-benalaxyl half-life slightly } \\
\text { smaller and relative enrichment of the } \\
(R) \text {-enantiomer occurred }\end{array}$ & [136] \\
\hline furalaxyl, metalaxyl & $\begin{array}{l}\text { microbial liquid } \\
\text { cultures }\end{array}$ & $\begin{array}{l}\text { laboratory incubation } \\
\text { experiments with the individual } \\
\text { compounds and its mixture }\end{array}$ & HPLC-MS & $\begin{array}{l}\text { enantioselective degradation of furalaxyl } \\
\text { and metalaxyl observed with one of the } \\
\text { isolated microorganisms; }(R) \text {-enantiomers } \\
\text { of both compounds preferentially } \\
\text { degraded }\end{array}$ & [137] \\
\hline
\end{tabular}


Table 2. Cont.

\begin{tabular}{|c|c|c|c|c|c|}
\hline Chiral Pesticide & Matrix & Biodegradation Experiment & Analytical Method & EF/Observations & Reference \\
\hline metalaxyl & sewage sludge & $\begin{array}{l}\text { laboratory incubation } \\
\text { experiments under anaerobic } \\
\text { conditions }\end{array}$ & HPLC-UV-CD & $\begin{array}{l}\text { (S)-metalaxyl from the racemic mixture } \\
\text { degraded faster, presenting a } \mathrm{T}_{1 / 2} \text { much } \\
\text { lower than the }(R) \text {-metalaxyl; racemic } \\
\text { mixture } \mathrm{T}_{1 / 2} \text { lower than the } \\
(R) \text {-enantiomer }\end{array}$ & [138] \\
\hline phenylpyrazoles & - & - & - & - & \\
\hline fipronil & sediment & $\begin{array}{l}\text { laboratory incubation } \\
\text { experiments under anaerobic } \\
\text { conditions }\end{array}$ & GC-MS & $\begin{array}{l}\text { enantioselective degradation of fipronil } \\
\text { observed; fipronil EF varied during } \\
\text { incubation period in sulfidogenic } \\
\text { sediments and the }(S) \text {-enantiomer was } \\
\text { preferentially degraded }\end{array}$ & [139] \\
\hline fipronil & soil & $\begin{array}{l}\text { laboratory incubation } \\
\text { experiments under aerobic and } \\
\text { anaerobic conditions }\end{array}$ & HPLC-DAD & $\begin{array}{l}\text { almost non-enantioselective degradation } \\
\text { of racemic fipronil observed; (S)-fipronil } \\
\text { preferentially degraded under anaerobic } \\
\text { conditions with flooded soil; no } \\
\text { enantiomerization of fipronil observed }\end{array}$ & [140] \\
\hline fipronil & algae cultures & $\begin{array}{l}\text { laboratory incubation } \\
\text { experiments with racemic } \\
\text { mixture and individual } \\
\text { enantiomers }\end{array}$ & HPLC-UV & $\begin{array}{l}\text { enantioselective degradation of fipronil } \\
\text { observed; EF varied from } 0.5 \text { to } 0.65 \text { in } 17 \\
\text { days; longer half-life values observed for } \\
\text { (S)-fipronil }\end{array}$ & [141] \\
\hline pyrethroids & - & - & - & - & - \\
\hline alpha-cypermethrin & soil & $\begin{array}{l}\text { laboratory incubation } \\
\text { experiments }\end{array}$ & HPLC-VWD; GC-ECD & $\begin{array}{l}\text { enantioselective degradation of } \\
\alpha \text {-cypermethrin observed; EF varied from } \\
0.55 \text { to } 0.61 \text { in } 42 \text { days; } \\
(+)-(1 R, \text { cis, } \alpha S) \text {-cypermethrin } \\
\text { preferentially degraded }\end{array}$ & [142] \\
\hline beta-cypermethrin & soil & $\begin{array}{l}\text { laboratory incubation } \\
\text { experiments under sterile and } \\
\text { non-sterile conditions }\end{array}$ & HPLC-VWD & $\begin{array}{l}\text { enantioselective degradation of } \\
\text { beta-cypermethrin observed; different } \\
\text { degradation rates observed for the four } \\
\text { beta-cypermethrin isomers; EF variation } \\
\text { noticed during the degradation process }\end{array}$ & [143] \\
\hline beta-cypermethrin- & soil & $\begin{array}{l}\text { laboratory incubation } \\
\text { experiments under sterile and } \\
\text { non-sterile conditions with acidic } \\
\text { and alkaline matrices, and with } \\
\text { racemic mixture and individual } \\
\text { enantiomers }\end{array}$ & HPLC-UV & $\begin{array}{l}\text { enantioselective degradation of } \\
\text { racemic-beta-cypermethrin observed only } \\
\text { in non-sterile soils; different degradation } \\
\text { rates and half-lives observed for the four } \\
\text { beta-cypermethrin isomers; no } \\
\text { enantiomeric enrichment observed during } \\
\text { degradation of individual enantiomers }\end{array}$ & [144] \\
\hline
\end{tabular}


Table 2. Cont

\begin{tabular}{|c|c|c|c|c|c|}
\hline Chiral Pesticide & Matrix & Biodegradation Experiment & Analytical Method & EF/Observations & Reference \\
\hline $\begin{array}{l}\text { (Z)-cis-bifenthrin, cis-permethrin, } \\
\text { cyfluthrin, cypermethrin }\end{array}$ & soil, sediment & $\begin{array}{l}\text { laboratory incubation } \\
\text { experiments under aerobic and } \\
\text { anaerobic conditions }\end{array}$ & GC-ECD & $\begin{array}{l}\text { enantioselective degradation of } \\
\text { cis-bifemthrin, pemethrin and cyfluthrin } \\
\text { observed }\end{array}$ & [145] \\
\hline fenpropathrin, fenvalerate & soil & $\begin{array}{l}\text { laboratory incubation } \\
\text { experiments with acidic and } \\
\text { alkaline matrices }\end{array}$ & HPLC-UV & $\begin{array}{l}\text { slightly enantioselective degradation of } \\
\text { fenpropathrin and fenvalerate in alkaline } \\
\text { samples where }(S) \text {-fenpropathrin and } \\
(\alpha S, 2 R) \text {-fenvalerate were degraded faster; } \\
\text { racemization observed in alkaline samples } \\
\text { but not on acidic soils }\end{array}$ & [146] \\
\hline triazoles & - & - & - & - & - \\
\hline epoxiconazole, cyproconazole & soil & $\begin{array}{l}\text { laboratory incubation } \\
\text { experiments under different } \mathrm{pH} \\
\text { conditions }\end{array}$ & GC-MS & $\begin{array}{l}\text { soil } \mathrm{pH} \text { affected degradation } \\
\text { enantioselectivity; enantioselective } \\
\text { degradation of epoxiconazole observed at } \\
\text { higher } \mathrm{pH} \text { values }\end{array}$ & [147] \\
\hline enilconazole & soil & $\begin{array}{l}\text { laboratory incubation } \\
\text { experiments under different } \\
\text { conditions of light and UV } \\
\text { irradiation }\end{array}$ & $\mathrm{CE}$ & $\begin{array}{l}\text { enantioselective degradation of } \\
\text { enilconazole not observed in alkaline soil }\end{array}$ & [148] \\
\hline $\begin{array}{c}\text { fenbuconazole, RH-9129 } \\
\text { (metabolite), RH-9130 (metabolite) }\end{array}$ & soil & $\begin{array}{l}\text { laboratory incubation } \\
\text { experiments under aerobic and } \\
\text { anaerobic conditions }\end{array}$ & LC-MS/MS & $\begin{array}{l}\text { enantioselective degradation of } \\
\text { fenbuconazole observed under aerobic and } \\
\text { anaerobic conditions; (-)-fenbuconazole } \\
\text { preferentially degraded; enantioselective } \\
\text { degradation of the metabolites differed } \\
\text { with aeration and pH conditions }\end{array}$ & [21] \\
\hline $\begin{array}{l}\text { flutriafol, hexaconazole, } \\
\text { tebuconazole }\end{array}$ & sediment & $\begin{array}{l}\text { laboratory incubation } \\
\text { experiments under sterile and } \\
\text { non-sterile conditions }\end{array}$ & HPLC-UV & $\begin{array}{l}\text { enantioselective degradation of the three } \\
\text { triazole fungicides observed; } \\
\text { (-)-enantiomers preferentially degraded in } \\
\text { native conditions; no significant } \\
\text { enantioselective degradation observed } \\
\text { under sterilized conditions }\end{array}$ & [155] \\
\hline triadimefon & soil & $\begin{array}{l}\text { laboratory incubation } \\
\text { experiments in sterile and } \\
\text { non-sterile conditions }\end{array}$ & HPLC-UV & $\begin{array}{l}(R) \text {-triadimefon preferentially degraded in } \\
\text { acidic and alkaline soils; racemization } \\
\text { observed in the abiotic degradation of } \\
\text { enantiopure triadimefon enantiomers }\end{array}$ & [150] \\
\hline
\end{tabular}


Table 2. Cont.

\begin{tabular}{|c|c|c|c|c|c|}
\hline Chiral Pesticide & Matrix & Biodegradation Experiment & Analytical Method & EF/Observations & Reference \\
\hline triadimenol & soil & $\begin{array}{l}\text { laboratory incubation } \\
\text { experiments in sterile and } \\
\text { non-sterile conditions }\end{array}$ & HPLC-UV & $\begin{array}{l}\text { relative enantioselective degradation of } \\
\text { triadimenol observed; epimerization } \\
\text { observed in incubations with enantiopure } \\
\text { triadimenol enantiomers }\end{array}$ & [151] \\
\hline tebuconazole & $\begin{array}{l}\text { agricultural soil, } \\
\text { vegetables }\end{array}$ & $\begin{array}{l}\text { laboratory incubation } \\
\text { experiments in sterile and } \\
\text { non-sterile conditions }\end{array}$ & $\begin{array}{l}\text { HPLC-DAD, } \\
\text { LC-MS/MS }\end{array}$ & $\begin{array}{l}\text { tebuconazole EF varied slightly during } \\
\text { biodegradation in soil samples; } \\
\text { (R)-tebuconazole degraded faster than the } \\
\text { (S)-enantiomer in tested soils }\end{array}$ & [152] \\
\hline tebuconazole, myclobutanil & soil & $\begin{array}{l}\text { laboratory incubation } \\
\text { experiments under aerobic and } \\
\text { anaerobic conditions with } \\
\text { racemic mixture and individual } \\
\text { enantiomers }\end{array}$ & LC-MS/MS & $\begin{array}{l}\text { enantioselective degradation of } \\
\text { tebuconazole observed in aerobic and } \\
\text { anaerobic soils; }(S) \text {-tebuconazole } \\
\text { preferentially degraded; enantioselectivity } \\
\text { correlated with the soils organic carbon } \\
\text { content; (+)-myclobutanil preferentially } \\
\text { degraded in aerobic soils; similar } \\
\text { degradation rates of myclobutanil } \\
\text { enantiomers in anaerobic soils }\end{array}$ & [153] \\
\hline
\end{tabular}

Notes: CE, capillary electrophoresis; CD, circular dichroism; ECD, electron capture detector; ECNI, electron capture negative ion; LSC, liquid scintillation counter; VWD, variable wavelength detector. 


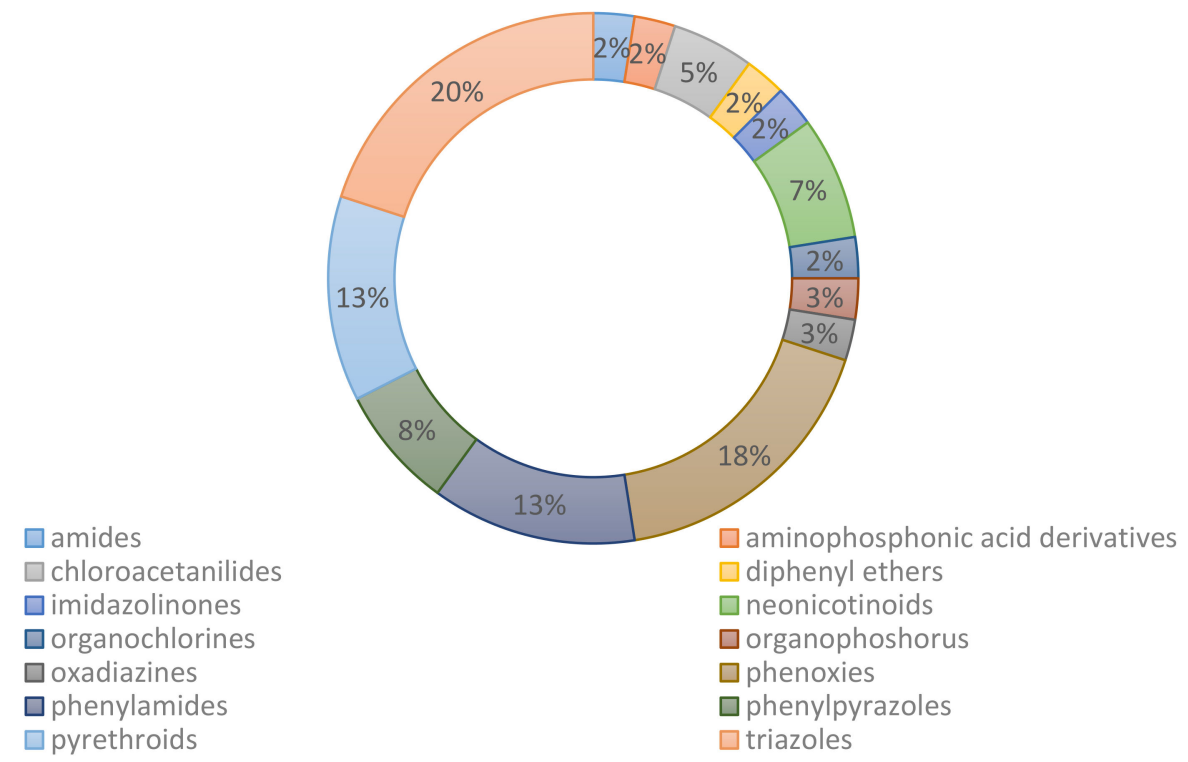

Figure 4. Relative percentages of each pesticide classes mentioned in the reviewed enantioselective biodegradation studies.

Regarding the analytical methods used to quantify pesticides' enantiomers during biodegradation, the trend is clear and high-performance liquid chromatography with a diode array detector (HPLC-DAD) [117,122,123,126,128,134,135,140,152] and an ultraviolet detector (UV) $[120,129,132,136,138,141,144,146,150,151,155]$, as well as liquid chromatography tandem-mass spectrometry (LC-MS/MS) [21,121,123,130,131,152,153], are the predominant quantification approaches employed. Other analytical methods have been reported, such as GC [116,118,124,133,139,145,147,154] and capillary electrophoresis [148]. Chromatographic stopped-flow techniques have been used to monitor enantiomerization studies [168]. All the works with GC described direct enantioselective methods using cyclodextrin-based CSP, the CSP most often applied in enantioselective analysis of organochlorine compounds $[169,170]$. Enantioselective LC-MS/MS methods performed direct chiral analysis, mostly using polysaccharide-based CSP [21,123,130,152,153], although the utilization of a cyclodextrin-based CSP was also described [131]. Soil is the major matrix used in pesticides' biodegradation studies, accounting for more than $70 \%$ of the works considered in this review, probably because it is the primary environmental compartment with which they are in contact. This matrix choice propensity in biodegradation studies with pesticides is clearly different to that observed for pharmaceuticals and drugs of abuse, where environmental waters are the main matrix used.

Triazole fungicides are the class with a higher number of compounds employed in biodegradation studies. Enantioselectivity was observed for all triazole compounds considered, although at different degrees depending on experimental conditions such as aeration and $\mathrm{pH}$ range $[21,147,148,150,153]$. A comprehensive study with fenbuconazole conducted with soil in laboratory incubation experiments monitored not only the biodegradation of the target fungicide but also the formation and biodegradation of two chiral metabolites [21]. Results demonstrated enantioselectivity during the biodegradation of fenbuconazole and during the biodegradation of the two chiral metabolites monitored, in which the (+)-enantiomer of the parent compound was preferentially degraded - the opposite of the pattern observed for the metabolites with (-)-enantiomers, which degraded faster and to a larger extent. Epoxiconazole biodegradation in soil exhibited greater enantioselectivity at higher $\mathrm{pH}$ levels [147]. Conversely, the biodegradation of enilconazole in soil samples at alkaline $\mathrm{pH}$ was not enantioselective [148]. Triadimefon-enantioselective biodegradation was observed at acidic and alkaline $\mathrm{pH}$ levels in a similar matrix, and in both conditions the 
$(R)$-enantiomer was preferentially degraded [150]. $\mathrm{pH}^{\prime} \mathrm{s}$ impact on biodegradation has been correlated with enzymatic reactions and microbiological activity and can, consequently, affect the enantioselectivity of the degradative course $[148,171]$. These results suggest that, as well as for the matrix chemical characteristics, the specific individual structure of a compound has a great impact on its enantioselective behavior during degradative processes, and different outcomes regarding the enantioselectivity may be obtained for compounds that are chemically related.

Phenoxy herbicides are another pesticide class frequently used to assess enantioselectivity during biodegradation. Generally, all the studies reported enantioselective biodegradation to some extent in the various matrices considered (for instance, algae cultures, agricultural soil, sediment, water, and vegetables) [127-130]. Diclofop-methyl exhibited diverse enantioselective behaviors in different biodegradation matrices, with its (-)-enantiomer being degraded faster in soil samples and more slowly in Chinese cabbage samples [128]. The same multiplicity of enantioselective behaviors was observed for fluazifop-butyl, which was enantioselectively biodegraded in soil, though the enantiomer preferentially degraded varied within samples, while its degradation on water samples was non-enantioselective [130].

Fipronil is a phenylpyrazole broad-spectrum insecticide broadly used on house pets as well as in pest control on agricultural fields [139]. Different works reported the biodegradation of fipronil in several matrices (sediment, soil, and algae cultures) [139-141]. Fipronil biodegradation was enantioselective, although with different contours: in sediment samples the (S)-enantiomer was preferentially degraded and variations in the EF were observed during the degradation period [139]; in algae cultures the EF of racemic fipronil also varied during the degradation period but the (S)-enantiomer had longer half-life values, persisting longer in the medium [141]; and in soil samples the racemic fipronil biodegradation was almost non-enantioselective, even though the $(S)$-enantiomer was slightly more degraded under anaerobic conditions [140].

Benalaxyl is a phenylamide fungicide widely used in tomato, grape, potato, tobacco, and soybean crops; its biodegradation has been reported as enantioselective in different matrices as soil, plants and vegetables [134,135], and freshwater algae cultures [136]. Biodegradation in plants and vegetables showed faster degradation of (S)-benalaxyl in diverse experimental conditions, while experiments in soil reported preferential degradation of $(R)$-benalaxyl $[134,135]$. (S)-benalaxyl exhibited somewhat smaller half-life values in freshwater algae cultures and in the same study enrichment of the $(R)$-enantiomer was also reported [136]. Degradation in vegetables also resulted in $(R)$-benalaxyl enrichment [135].

Beta-cypermethrin is a pyrethroid insecticide with four isomers and is one of the most used worldwide, notwithstanding its well-known toxic effects against different organisms and environmental compartments $[1,25,172]$. Two different studies on soils reported the enantioselective biodegradation of beta-cypermethrin $[143,144]$ and in both works different degradation rates and extents were observed for the four isomers. Additionally, no enantiomeric enrichment was detected when enantiopure isomers were employed in biodegradation experiments [144].

All the works discussed here reinforce the importance of developing enantioselective methods to determine the $\mathrm{EF}$ of chiral organic pollutants in the environment and to encourage more concern about the stereochemistry in this field. Concerning enantioselective biodegradation studies, samples tend to be cleaner and with higher concentration than in soils, effluents, and surface water samples, allowing for easier sample preparation process and feasibility in EF quantification $[173,174]$.

\section{Conclusions and Future Perspectives}

Overall regardless of the great importance given to chiral organic pollutants, the stereochemistry involved in biodegradation is still frequently overlooked. Although enantioselective methods and biodegradation experiments have evolved in recent years, namely regarding pesticide compounds, studies with chiral pharmaceuticals and drugs of abuse are nonetheless only a minor part of the research work in this field. The study of enantioselective processes associated with the formation 
and degradation of chiral metabolites of chiral compounds is practically non-existent. In addition to the occurrence and environmental fate of the metabolites and products of transformation of chiral pollutants, it is of great importance to evaluate the inherent enantioselectivity given their potential consequences for the environment.

The understanding of the impact of stereoselectivity on the degradation and transformation of chiral organic compounds in environmental matrices and non-target organisms is key for an improved environmental risk assessment of these pollutants, since these developments can represent unexpected ecotoxicological effects. Further knowledge of enantioselective environmental processes could help the agrochemical industry to redirect production of broadly applied chiral compounds to enriched- or single-enantiomer formulations, thus reducing the pollutant load of racemic mixtures into the environment.

Acknowledgments: The authors wish to thank Fundação para a Ciência e Tecnologia-FCT for financial support under the project Fluoropharma PTDC/EBB-EBI/111699/2009, the PhD grant attributed to Alexandra S. Maia SFRH/BD/86939/2012, QREN-POPH, European Social Fund, MCTES, PEst FCOMP-01-0124-FEDER-022718; PEst-OE/EQB/LA0016/2011, PEst-OE/SAU/UI4040/2014. This research was partially supported by the Strategic Funding UID/Multi/04423/2013 through national funds provided by FCT—Fundação para a Ciência e Tecnologia and European Regional Development Fund (ERDF), in the framework of the program PT2020 and by CESPU (ChiralDrugs_CESPU_2017).

Author Contributions: Maria Elizabeth Tiritan and Paula M. L. Castro designed the work; Alexandra S. Maia and Ana R. Ribeiro analyzed and reunited the data; Maria Elizabeth Tiritan, Alexandra S. Maia and Ana R. Ribeiro wrote the paper.

Conflicts of Interest: The authors declare no conflict of interest.

\section{References}

1. Wong, C.S. Environmental fate processes and biochemical transformations of chiral emerging organic pollutants. Anal. Bioanal. Chem. 2006, 386, 544-558. [CrossRef] [PubMed]

2. Sekhon, B.S. Chiral pesticides. J. Pestic. Sci. 2009, 34, 1-12. [CrossRef]

3. Wainer, I.W.; Drayer, D.E. Drug Stereochemistry: Analytical Methods and Pharmacology (Clinical Pharmacology, no 18), 2nd ed.; Marcel Dekker: New York, NY, USA, 1993; p. 432.

4. Kurihara, N.; Miyamoto, J.; Paulson, G.D.; Zeeh, B.; Skidmore, M.W.; Hollingworth, R.M.; Kuiper, H.A. Pesticides report 37: Chirality in synthetic agrochemicals: Bioactivity and safety consideration (technical report). Pure Appl. Chem. 1997, 69, 2007-2026.

5. Ribeiro, A.R.; Maia, A.S.; Cass, Q.B.; Tiritan, M.E. Enantioseparation of chiral pharmaceuticals in biomedical and environmental analyses by liquid chromatography: An overview. J. Chromatogr. B 2014, 968, 8-21. [CrossRef] [PubMed]

6. Chen, J.; Korfmacher, W.A.; Hsieh, Y. Chiral liquid chromatography-tandem mass spectrometric methods for stereoisomeric pharmaceutical determinations. J. Chromatogr. B 2005, 820, 1-8. [CrossRef] [PubMed]

7. Ye, J.; Zhao, M.; Niu, L.; Liu, W. Enantioselective environmental toxicology of chiral pesticides. Chem. Res. Toxicol. 2015, 28, 325-338. [CrossRef] [PubMed]

8. Buser, H.-R.; Poiger, T.; Muller, M.D. Occurrence and environmental behavior of the chiral pharmaceutical drug ibuprofen in surface waters and in wastewater. Environ. Sci. Technol. 1999, 33, 2529-2535. [CrossRef]

9. Schurig, V. Terms for the quantitation of a mixture of stereoisomers. In Differentiation of Enantiomers I; Schurig, V., Ed.; Springer International Publishing: Cham, Switzerland, 2013; pp. 21-40.

10. Lao, W.; Gan, J. Enantioselective degradation of warfarin in soils. Chirality 2012, 24, 54-59. [CrossRef] [PubMed]

11. Patrick, R.; Jan, S.; Andreas, S.; Timm, K.; Burkhard, S. First evidence for a stereoselective incorporation of nonylphenol diastereomers in soil-derived organo-clay complexes. Environ. Chem. Lett. 2011, 9, 293-299. [CrossRef]

12. Petrie, B.; Barden, R.; Kasprzyk-Hordern, B. A review on emerging contaminants in wastewaters and the environment: Current knowledge, understudied areas and recommendations for future monitoring. Water Res. 2015, 72, 3-27. [CrossRef] [PubMed] 
13. Zipper, C.; Suter, M.J.F.; Haderlein, S.B.; Gruhl, M.; Kohler, H.P. Changes in the enantiomeric ratio of (r)-to (s)-mecoprop indicate in situ biodegradation of this chiral herbicide in a polluted aquifer. Environ. Sci. Technol. 1998, 32, 2070-2076. [CrossRef]

14. Liu, W.; Gan, J.; Schlenk, D.; Jury, W.A. Enantioselectivity in environmental safety of current chiral insecticides. Proc. Natl. Acad. Sci. USA 2005, 102, 701-706. [CrossRef] [PubMed]

15. Liu, W.; Ye, J.; Jin, M. Enantioselective phytoeffects of chiral pesticides. J. Agric. Food Chem. 2009, 57, 2087-2095. [CrossRef] [PubMed]

16. Garrison, A.W.; Schmitt, P.; Martens, D.; Kettrup, A. Enantiomeric selectivity in the environmental degradation of dichlorprop as determined by high-performance capillary electrophoresis. Environ. Sci. Technol. 1996, 30, 2449-2455. [CrossRef]

17. Nikolai, L.N.; McClure, E.L.; Macleod, S.L.; Wong, C.S. Stereoisomer quantification of the beta-blocker drugs atenolol, metoprolol, and propranolol in wastewaters by chiral high-performance liquid chromatography-tandem mass spectrometry. J. Chromatogr. A 2006, 1131, 103-109. [CrossRef] [PubMed]

18. Sanganyado, E.; Lu, Z.; Fu, Q.; Schlenk, D.; Gan, J. Chiral pharmaceuticals: A review on their environmental occurrence and fate processes. Water Res. 2017, 124, 527-542. [CrossRef] [PubMed]

19. Sanganyado, E.; Fu, Q.; Gan, J. Enantiomeric selectivity in adsorption of chiral $\beta$-blockers on sludge. Environ. Pollut. 2016, 214, 787-794. [CrossRef] [PubMed]

20. Oravec, M.; Šimek, Z.; Holoubek, I. The effect of humic acid and ash on enantiomeric fraction change of chiral pollutants. Colloids Surf. Physicochem. Eng. Aspects 2010, 359, 60-65. [CrossRef]

21. Li, Y.; Dong, F.; Liu, X.; Xu, J.; Li, J.; Kong, Z.; Chen, X.; Zheng, Y. Environmental behavior of the chiral triazole fungicide fenbuconazole and its chiral metabolites: Enantioselective transformation and degradation in soils. Environ. Sci. Technol. 2012, 46, 2675-2683. [CrossRef] [PubMed]

22. Ariens, E.J.; Van Rensen, J.J.S.; Welling, W. Stereoselectivity of Pesticides: Biological and Chemical Problems; Elsevier: Amsterdam, The Netherlands, 1988; Volume 1.

23. Wink, O.; Luley, U. Enantioselective transformation of the herbicides diclofop-methyl and fenoxaprop-ethyl in soil. Pest Manage. Sci. 1988, 22, 31-40. [CrossRef]

24. Hashim, N.H.; Shafie, S.; Khan, S.J. Enantiomeric fraction as an indicator of pharmaceutical biotransformation during wastewater treatment and in the environment-a review. Environ. Technol. 2010, 31, 1349-1370. [CrossRef] [PubMed]

25. Ye, J.; Zhao, M.; Liu, J.; Liu, W. Enantioselectivity in environmental risk assessment of modern chiral pesticides. Environ. Pollut. 2010, 158, 2371-2383. [CrossRef] [PubMed]

26. Hühnerfuss, H.; Shah, M.R. Enantioselective chromatography-A powerful tool for the discrimination of biotic and abiotic transformation processes of chiral environmental pollutants. J. Chromatogr. A 2009, 1216, 481-502. [CrossRef] [PubMed]

27. Santos, L.H.; Araújo, A.N.; Fachini, A.; Pena, A. Ecotoxicological aspects related to the presence of pharmaceuticals in the aquatic environment. J. Hazard. Mater. 2010, 175, 45-95. [CrossRef] [PubMed]

28. Gunnarsdóttir, R.; Jenssen, P.D.; Erland Jensen, P.; Villumsen, A.; Kallenborn, R. A review of wastewater handling in the arctic with special reference to pharmaceuticals and personal care products (ppcps) and microbial pollution. Ecol. Eng. 2013, 50, 76-85. [CrossRef]

29. Comission, E. Proposal for a directive of the european parliament and of the council amending directives 2000/60/ec and 2008/105/ec as regards priority substances in the field of water policy. Off. J. Eur. Union 2012, 78, 40 .

30. Decision_495. Commission implementing decision (eu) 2015/495 of 20 march 2015 establishing a watch list of substances for union-wide monitoring in the field of water policy pursuant to directive 2008/105/ec of the european parliament and of the council. Off. J. Eur. Union 2015, L78, 40-42.

31. Daughton, C.G. Pharmaceutical ingredients in drinking water: Overview of occurrence and significance of human exposure. In Contaminants of Emerging Concern in the Environment: Ecological and Human Health Considerations; American Chemical Society: Washington DC, USA, 2010; Volume 1048, pp. 9-68.

32. Daughton, C.G.; Ternes, T.A. Pharmaceuticals and personal care products in the environment: Agents of subtle change? Environ. Health Perspect. 1999, 107 (Suppl. 6), 907-938. [CrossRef] [PubMed]

33. Rivera-Utrilla, J.; Sánchez-Polo, M.; Ferro-García, M.Á.A.; Prados-Joya, G.; Ocampo-Pérez, R. Pharmaceuticals as emerging contaminants and their removal from water. A review. Chemosphere 2013, 93, 1268-1287. [CrossRef] [PubMed] 
34. Kümmerer, K. The presence of pharmaceuticals in the environment due to human use-present knowledge and future challenges. J. Environ. Manage. 2009, 90, 2354-2366. [CrossRef] [PubMed]

35. Tijani, J.; Fatoba, O.; Petrik, L.F. A review of pharmaceuticals and endocrine-disrupting compounds: Sources, effects, removal, and detections. Water, Air, Soil Pollut. 2013, 224, 1-29. [CrossRef]

36. Luo, Y.; Guo, W.; Ngo, H.H.; Nghiem, L.D.; Hai, F.I.; Zhang, J.; Liang, S.; Wang, X.C. A review on the occurrence of micropollutants in the aquatic environment and their fate and removal during wastewater treatment. Sci. Total Environ. 2014, 473-474, 619-641. [CrossRef] [PubMed]

37. Verlicchi, P.; Zambello, E. How efficient are constructed wetlands in removing pharmaceuticals from untreated and treated urban wastewaters? A review. Sci. Total Environ. 2014, 470-471, 1281-1306. [CrossRef] [PubMed]

38. Mohapatra, D.P.; Brar, S.K.; Tyagi, R.D.; Picard, P.; Surampalli, R.Y. Analysis and advanced oxidation treatment of a persistent pharmaceutical compound in wastewater and wastewater sludge-carbamazepine. Sci. Total Environ. 2014, 470-471, 58-75. [CrossRef] [PubMed]

39. Jelic, A.; Gros, M.; Ginebreda, A.; Cespedes-Sánchez, R.; Ventura, F.; Petrovic, M.; Barcelo, D. Occurrence, partition and removal of pharmaceuticals in sewage water and sludge during wastewater treatment. Water Res. 2011, 45, 1165-1176. [CrossRef] [PubMed]

40. Lajeunesse, A.; Smyth, S.A.; Barclay, K.; Sauvé, S.; Gagnon, C. Distribution of antidepressant residues in wastewater and biosolids following different treatment processes by municipal wastewater treatment plants in canada. Water Res. 2012, 46, 5600-5612. [CrossRef] [PubMed]

41. Agranat, I.; Wainschtein, S.R.; Zusman, E.Z. The predicated demise of racemic new molecular entities is an exaggeration. Nat. Rev. Drug Discov. 2012, 11, 972-973. [CrossRef] [PubMed]

42. Ribeiro, A.R.; Castro, P.M.L.; Tiritan, M.E. Chiral pharmaceuticals in the environment. Environ. Chem. Lett. 2012, 10, 239-253. [CrossRef]

43. López-Serna, R.; Kasprzyk-Hordern, B.; Petrović, M.; Barceló, D. Multi-residue enantiomeric analysis of pharmaceuticals and their active metabolites in the guadalquivir river basin (south spain) by chiral liquid chromatography coupled with tandem mass spectrometry. Anal. Bioanal. Chem. 2013, 405, 5859-5873. [CrossRef] [PubMed]

44. Ribeiro, A.; Santos, L.; Maia, A.S.; Delerue-Matos, C.; Castro, P.M.L.; Tiritan, M.E. Enantiomeric fraction evaluation of pharmaceuticals in environmental matrices by liquid chromatography-tandem mass spectrometry. J. Chromatogr. A 2014, 1363, 226-235. [CrossRef] [PubMed]

45. Evans, S.E.; Davies, P.; Lubben, A.; Kasprzyk-Hordern, B. Determination of chiral pharmaceuticals and illicit drugs in wastewater and sludge using microwave assisted extraction, solid-phase extraction and chiral liquid chromatography coupled with tandem mass spectrometry. Anal. Chim. Acta 2015, 882, 112-126. [CrossRef] [PubMed]

46. Tiritan, M.E.; Ribeiro, A.R.; Fernandes, C.; Pinto, M.M.M. Chiral pharmaceuticals. Kirk-Othmer Encycl. Chem. Technol. 2016. [CrossRef]

47. Stanley, J.K.; Brooks, B.W. Perspectives on ecological risk assessment of chiral compounds. Integr. Environ. Assess. Manage. 2009, 5, 364-373. [CrossRef]

48. De Andrés, F.; Castañeda, G.; Ríos, Á. Use of toxicity assays for enantiomeric discrimination of pharmaceutical substances. Chirality 2009, 21, 751-759. [CrossRef] [PubMed]

49. Bagnall, J.P.; Evans, S.E.; Wort, M.T.; Lubben, A.T.; Kasprzyk-Hordern, B. Using chiral liquid chromatography quadrupole time-of-flight mass spectrometry for the analysis of pharmaceuticals and illicit drugs in surface and wastewater at the enantiomeric level. J. Chromatogr. A 2012, 1249, 115-129. [CrossRef] [PubMed]

50. Hashim, N.H.; Khan, S.J. Enantioselective analysis of ibuprofen, ketoprofen and naproxen in wastewater and environmental water samples. J. Chromatogr. A 2011, 1218, 4746-4754. [CrossRef] [PubMed]

51. Kasprzyk-Hordern, B. Pharmacologically active compounds in the environment and their chirality. Chem. Soc. Rev. 2010, 39, 4466-4503. [CrossRef] [PubMed]

52. Kasprzyk-Hordern, B.; Baker, D.R. Enantiomeric profiling of chiral drugs in wastewater and receiving waters. Environ. Sci. Technol. 2012, 46, 1681-1691. [CrossRef] [PubMed]

53. Kasprzyk-Hordern, B.; Baker, D.R. Estimation of community-wide drugs use via stereoselective profiling of sewage. Sci. Total Environ. 2012, 423, 142-150. [CrossRef] [PubMed] 
54. Caballo, C.; Sicilia, M.D.; Rubio, S. Enantioselective determination of representative profens in wastewater by a single-step sample treatment and chiral liquid chromatography-tandem mass spectrometry. Talanta 2015, 134, 325-332. [CrossRef] [PubMed]

55. Ribeiro, A.R.; Castro, P.M.L.; Tiritan, M. Environmental Fate of Chiral Pharmaceuticals: Determination, Degradation and Toxicity; Springer: Cham, Switzerland, 2012; pp. 3-45.

56. Barclay, V.K.H.; Tyrefors, N.L.; Johansson, I.M.; Pettersson, C.E. Trace analysis of fluoxetine and its metabolite norfluoxetine. Part ii: Enantioselective quantification and studies of matrix effects in raw and treated wastewater by solid phase extraction and liquid chromatography-tandem mass spectrometry. J. Chromatogr. A 2012, 1227, 105-114. [CrossRef] [PubMed]

57. Barclay, V.K.H.; Tyrefors, N.L.; Johansson, I.M.; Pettersson, C.E. Chiral analysis of metoprolol and two of its metabolites, $\alpha$-hydroxymetoprolol and deaminated metoprolol, in wastewater using liquid chromatography-tandem mass spectrometry. J. Chromatogr. A 2012, 1269, 208-217. [CrossRef] [PubMed]

58. DeLorenzo, M.E.; Scott, G.I.; Ross, P.E. Toxicity of pesticides to aquatic microorganisms: A review. Environ. Toxicol. Chem. 2001, 20, 84-98. [CrossRef] [PubMed]

59. Aktar, W.; Sengupta, D.; Chowdhury, A. Impact of pesticides use in agriculture: Their benefits and hazards. Interdiscip. Toxicol. 2009, 2, 1-12. [CrossRef] [PubMed]

60. World Health Organization. Pesticides and Their Application: For the Control of Vectors and Pests of Public Health Importance, 6th ed.; WHO: Geneva, Switzerland, 2006; pp. 1-114.

61. Magri, A.; Haith, D.A. Pesticide decay in turf: A review of processes and experimental data. J. Environ. Qual. 2009, 38, 4-12. [CrossRef] [PubMed]

62. Farha, W.; El-Aty, A.M.A.; Rahman, M.M.; Shin, H.C.; Shim, J.H. An overview on common aspects influencing the dissipation pattern of pesticides: A review. Environ. Monit. Assess. 2016, 188, 693. [CrossRef] [PubMed]

63. Taylor, N.; Matthews, G. Effect of different adjuvants on the rainfastness of bendiocarb applied to brussels sprout plants. Crop Protect. 1986, 5, 250-253. [CrossRef]

64. Pick, F.E.; Van Dyk, L.P.; De Beer, P.R. The effect of simulated rain on deposits of some cotton pesticides. Pest Manage. Sci. 1984, 15, 616-623. [CrossRef]

65. Barceló, D. Occurrence, handling and chromatographic determination of pesticides in the aquatic environment-A review. Analyst 1991, 16, 681-689. [CrossRef]

66. Wauchope, R.D. The pesticide content of surface water draining from agricultural fields-A review. J. Environ. Qual. 1978, 7, 459-472. [CrossRef]

67. Kolpin, D.W.; Thurman, E.M.; Linhart, S.M. The environmental occurrence of herbicides: The importance of degradates in ground water. Arch. Environ. Contam. Toxicol. 1998, 35, 385-390. [CrossRef] [PubMed]

68. Calderbank, A. The occurrence and significance of bound pesticide residues in soil. In Reviews of Environmental Contamination and Toxicology; Ware, G.W., Ed.; Springer: New York, NY, USA, 1989; pp. 71-103.

69. Garrison, A.W. Chiral pesticides and polychlorinated biphenyl congeners in environmental samples, analysis of. In Encyclopedia of Analytical Chemistry; Myers, R.A., Ed.; John Wiley \& Sons, Ltd.: Chichester, UK, 2006; pp. 6147-6158.

70. Garrison, A.W. Issues on the enantioselectivity of chiral agrochemicals. Chimica oggi 2002, 20, $28-32$.

71. Dong, F.; Li, J.; Chankvetadze, B.; Cheng, Y. Chiral triazole fungicide difenoconazole: Absolute stereochemistry, stereoselective bioactivity, aquatic toxicity, and environmental behavior in vegetables and soil. Environ. Sci. Technol. 2013, 47, 3386-3394. [CrossRef] [PubMed]

72. Gámiz, B.; Facenda, G.; Celis, R. Evidence for the effect of sorption enantioselectivity on the availability of chiral pesticide enantiomers in soil. Environ. Pollut. 2016, 213, 966-973. [CrossRef] [PubMed]

73. Liu, H.; Ye, W.; Zhan, X.; Liu, W. A comparative study of rac- and s-metolachlor toxicity to daphnia magna. Ecotoxicol. Environ. Saf. 2006, 63, 451-455. [CrossRef] [PubMed]

74. Liu, W.; Gan, J.J.; Lee, S.; Werner, I. Isomer selectivity in aquatic toxicity and biodegradation of cypermethrin. J. Agric. Food Chem. 2004, 52, 6233-6238. [CrossRef] [PubMed]

75. Gasser, G.; Pankratov, I.; Elhanany, S.; Werner, P.; Gun, J.; Gelman, F.; Lev, O. Field and laboratory studies of the fate and enantiomeric enrichment of venlafaxine and o-desmethylvenlafaxine under aerobic and anaerobic conditions. Chemosphere 2012, 88, 98-105. [CrossRef] [PubMed]

76. Li, Z.; Gomez, E.; Fenet, H.; Chiron, S. Chiral signature of venlafaxine as a marker of biological attenuation processes. Chemosphere 2013, 90, 1933-1938. [CrossRef] [PubMed] 
77. Maia, A.S.; Castro, P.; Tiritan, M. Integrated liquid chromatography method in enantioselective studies: Biodegradation of ofloxacin by an activated sludge consortium. J. Chromatogr. B 2016, 1029, 174-183. [CrossRef] [PubMed]

78. Evans, S.E.; Bagnall, J.; Kasprzyk-Hordern, B. Enantioselective degradation of amphetamine-like environmental micropollutants (amphetamine, methamphetamine, mdma and mda) in urban water. Environ. Pollut. 2016, 215, 154-163. [CrossRef] [PubMed]

79. Bagnall, J.; Malia, L.; Lubben, A.; Kasprzyk-Hordern, B. Stereoselective biodegradation of amphetamine and methamphetamine in river microcosms. Water Res. 2013, 47, 5708-5718. [CrossRef] [PubMed]

80. Moreira, I.S.; Amorim, C.L.; Ribeiro, A.R.; Mesquita, R.B.R.; Rangel, A.O.S.S.; van Loosdrecht, M.C.M.; Tiritan, M.E.; Castro, P.M.L. Removal of fluoxetine and its effects in the performance of an aerobic granular sludge sequential batch reactor. J. Hazard. Mater. 2015, 287, 93-101. [CrossRef] [PubMed]

81. Hashim, N.H.; Nghiem, L.D.; Stuetz, R.M.; Khan, S.J. Enantiospecific fate of ibuprofen, ketoprofen and naproxen in a laboratory-scale membrane bioreactor. Water Res. 2011, 45, 6249-6258. [CrossRef] [PubMed]

82. Evans, S.; Bagnall, J.; Kasprzyk-Hordern, B. Enantiomeric profiling of a chemically diverse mixture of chiral pharmaceuticals in urban water. Environ. Pollut. 2017, 230, 368-377. [CrossRef] [PubMed]

83. Matamoros, V.; Hijosa, M.; Bayona, J.M. Assessment of the pharmaceutical active compounds removal in wastewater treatment systems at enantiomeric level. Ibuprofen and naproxen. Chemosphere 2009, 75, $200-205$. [CrossRef] [PubMed]

84. Winkler, M.; Lawrence, J.R.; Neu, T.R. Selective degradation of ibuprofen and clofibric acid in two model river biofilm systems. Water Res. 2001, 35, 3197-3205. [CrossRef]

85. Fono, L.J.; Sedlak, D.L. Use of the chiral pharmaceutical propranolol to identify sewage discharges into surface waters. Environ. Sci. Technol. 2005, 39, 9244-9252. [CrossRef] [PubMed]

86. Fono, L.J.; Kolodziej, E.P.; Sedlak, D.L. Attenuation of wastewater-derived contaminants in an effluent-dominated river. Environ. Sci. Technol. 2006, 40, 7257-7262. [CrossRef] [PubMed]

87. Ribeiro, A.R.; Afonso, C.M.; Castro, P.M.; Tiritan, M.E. Enantioselective biodegradation of pharmaceuticals, alprenolol and propranolol, by an activated sludge inoculum. Ecotoxicol. Environ. Saf. 2013, 87, 108-114. [CrossRef] [PubMed]

88. Ribeiro, A.; Afonso, C.; Castro, P.M.L.; Tiritan, M. Enantioselective hplc analysis and biodegradation of atenolol, metoprolol and fluoxetine. Environ. Chem. Lett. 2013, 11, 83-90. [CrossRef]

89. Moreira, I.S.; Ribeiro, A.R.; Afonso, C.M.; Tiritan, M.E.; Castro, P.M.L. Enantioselective biodegradation of fluoxetine by the bacterial strain labrys portucalensis f11. Chemosphere 2014, 111, 103-111. [CrossRef] [PubMed]

90. Ribeiro, A.R.; Maia, A.S.; Moreira, I.S.; Afonso, C.M. Enantioselective quantification of fluoxetine and norfluoxetine by hplc in wastewater effluents. Chemosphere 2014, 95, 589-596. [CrossRef] [PubMed]

91. Matamoros, V.; Uggetti, E.; García, J.; Bayona, J.M. Assessment of the mechanisms involved in the removal of emerging contaminants by microalgae from wastewater: A laboratory scale study. J. Hazard. Mater. 2016, 301, 197-205. [CrossRef] [PubMed]

92. Brienza, M.; Chiron, S. Enantioselective reductive transformation of climbazole: A concept towards quantitative biodegradation assessment in anaerobic biological treatment processes. Water Res. 2017, 116, 203-210. [CrossRef] [PubMed]

93. Amorim, C.L.; Moreira, I.S.; Ribeiro, A.R.; Santos, L.H.; Delerue-Matos, C.; Tiritan, M.E.; Castro, P.M. Treatment of a simulated wastewater amended with a chiral pharmaceuticals mixture by an aerobic granular sludge sequencing batch reactor. Int. Biodeterior. Biodegrad. 2016, 115, 277-285. [CrossRef]

94. Khan, S.J.; Wang, L.; Hashim, N.H.; McDonald, J.A. Distinct enantiomeric signals of ibuprofen and naproxen in treated wastewater and sewer overflow. Chirality 2014, 26, 739-746. [CrossRef] [PubMed]

95. MacLeod, S.L.; Sudhir, P.; Wong, C.S. Stereoisomer analysis of wastewater-derived $\beta$-blockers, selective serotonin re-uptake inhibitors, and salbutamol by high-performance liquid chromatography-tandem mass spectrometry. J. Chromatogr. A 2007, 1170, 23-33. [CrossRef] [PubMed]

96. Celis, R.; Gámiz, B.; Facenda, G.; Hermosín, M.C. Enantioselective sorption of the chiral fungicide metalaxyl on soil from non-racemic aqueous solutions: Environmental implications. J. Hazard. Mater. 2015, 300, 581-589. [CrossRef] [PubMed] 
97. Huang, Q.; Wang, Z.; Wang, C.; Peng, X. Chiral profiling of azole antifungals in municipal wastewater and recipient rivers of the pearl river delta, China. Environ. Sci. Pollut. Res. 2013, 20, 8890-8899. [CrossRef] [PubMed]

98. Giesen, A.; De Bruin, L.; Niermans, R.; Van der Roest, H. Advancements in the application of aerobic granular biomass technology for sustainable treatment of wastewater. Water Pract. Technol. 2013, 8, 2013007. [CrossRef]

99. Li, J.; Ding, L.-B.; Cai, A.; Huang, G.-X.; Horn, H. Aerobic sludge granulation in a full-scale sequencing batch reactor. BioMed Res. Int. 2014, 2014. [CrossRef] [PubMed]

100. Michael, I.; Rizzo, L.; McArdell, C.S.; Manaia, C.M.; Merlin, C.; Schwartz, T.; Dagot, C.; Fatta-Kassinos, D. Urban wastewater treatment plants as hotspots for the release of antibiotics in the environment: A review. Water Res. 2013, 47, 957-995. [CrossRef] [PubMed]

101. Maia, A.S.; Ribeiro, A.R.; Amorim, C.L.; Barreiro, J.C.; Cass, Q.B.; Castro, P.M.; Tiritan, M.E. Degradation of fluoroquinolone antibiotics and identification of metabolites/transformation products by liquid chromatography-tandem mass spectrometry. J. Chromatogr. A 2014, 1333, 87-98. [CrossRef] [PubMed]

102. Ferrando-Climent, L.; Collado, N.; Buttiglieri, G.; Gros, M.; Rodriguez-Roda, I.; Rodriguez-Mozaz, S.; Barceló, D. Comprehensive study of ibuprofen and its metabolites in activated sludge batch experiments and aquatic environment. Sci. Total Environ. 2012, 438, 404-413. [CrossRef] [PubMed]

103. Kirkland, K.; Fryer, J. Degradation of several herbicides in a soil previously treated with mcpa. Weed Res. 1972, 12, 90-95. [CrossRef]

104. Adkins, A. Degradation of the phenoxy acid herbicide diclofop-methyl by sphingomonas paucimobilis isolated from a canadian prairie soil. J. Ind. Microbiol. Biotechnol. 1999, 23, 332-335. [CrossRef] [PubMed]

105. Bromilow, R.H.; Evans, A.A.; Nicholls, P.H. Factors affecting degradation rates of five triazole fungicides in two soil types: 1. Laboratory incubations. Pest Manage. Sci. 1999, 55, 1129-1134.

106. Schneiderheinze, J.; Armstrong, D.; Berthod, A. Plant and soil enantioselective biodegradation of racemic phenoxyalkanoic herbicides. Chirality 1999, 11, 330-337. [CrossRef]

107. Weijers, C.; De Bont, J. Enantioselective degradation of 1, 2-epoxyalkanes by nocardia h8. Enzyme Microb. Technol. 1991, 13, 306-308. [CrossRef]

108. Heron, G.; Christensen, T.H. Degradation of the herbicide mecoprop in an aerobic aquifer determined by laboratory batch studies. Chemosphere 1992, 24, 547-557. [CrossRef]

109. Tett, V.; Willetts, A.; Lappin-Scott, H. Enantioselective degradation of the herbicide mecoprop [2-(2-methyl-4-chlorophenoxy) propionic acid] by mixed and pure bacterial cultures. FEMS Microbiol. Ecol. 1994, 14, 191-199. [CrossRef]

110. Buser, H.-R.; Mueller, M.D. Isomer and enantioselective degradation of hexachlorocyclohexane isomers in sewage sludge under anaerobic conditions. Environ. Sci. Technol. 1995, 29, 664-672. [CrossRef] [PubMed]

111. Zipper, C.; Nickel, K.; Angst, W.; Kohler, H. Complete microbial degradation of both enantiomers of the chiral herbicide mecoprop [(rs)-2-(4-chloro-2-methylphenoxy) propionic acid] in an enantioselective manner by sphingomonas herbicidovorans sp. Nov. Appl. Environ. Microbiol. 1996, 62, 4318-4322. [PubMed]

112. Parlar, H.; Fingerling, G.; Angerhöfer, D.; Christ, G.; Coelhan, M. Toxaphene residue composition as an indicator of degradation pathways. In Molecular Markers in Environmental Geochemistry; American Chemical Society: Washington DC, USA, 1997; Volume 671, pp. 346-364.

113. Zipper, C.; Bunk, M.; Zehnder, A.J.; Kohler, H.-P.E. Enantioselective uptake and degradation of the chiral herbicide dichlorprop [(rs)-2-(2, 4-dichlorophenoxy) propanoic acid] by sphingomonas herbicidovorans $\mathrm{mh}$. J. Bacteriol. 1998, 180, 3368-3374. [PubMed]

114. Zipper, C.; Fleischmann, T.; Kohler, H.-P.E. Aerobic biodegradation of chiral phenoxyalkanoic acid derivatives during incubations with activated sludge. FEMS Microbiol. Ecol. 1999, 29, 197-204. [CrossRef]

115. Müller, R.H.; Jorks, S.; Kleinsteuber, S.; Babel, W. Comamonas acidovorans strain mc1: A new isolate capable of degrading the chiral herbicides dichlorprop and mecoprop and the herbicides 2, 4- $\mathrm{d}$ and mcpa. Microbiol. Res. 1999, 154, 241-246. [CrossRef]

116. Buerge, I.J.; Müller, M.D.; Poiger, T. The chiral herbicide beflubutamid (ii): Enantioselective degradation and enantiomerization in soil, and formation/degradation of chiral metabolites. Environ. Sci. Technol. 2012, 47, 6812-6818. [CrossRef] [PubMed]

117. Zhang, K.-K.; Hu, D.-Y.; Zhu, H.-J.; Yang, J.-C.; Song, B.-A. Enantioselective degradation of dufulin in four types of soil. J. Agric. Food Chem. 2014, 62, 1771-1776. [CrossRef] [PubMed] 
118. Yun, M.; Wei-Ping, L.; Yue-Zhong, W. Enantioselective degradation of rac-metolachlor and s-metolachlor in soil11supported by the national science fund for distinguished young scholars (no. 20225721) and the national natural science foundation of china (no. 30270767). Pedosphere 2006, 16, 489-494.

119. Diao, J.; Xu, P.; Wang, P.; Lu, D.; Lu, Y.; Zhou, Z. Enantioselective degradation in sediment and aquatic toxicity to daphnia magna of the herbicide lactofen enantiomers. J. Agric. Food Chem. 2010, 58, 2439-2445. [CrossRef] [PubMed]

120. Wu, H.; He, X.; Dong, H.; Zhou, Q.; Zhang, Y. Impact of microorganisms, humidity, and temperature on the enantioselective degradation of imazethapyr in two soils. Chirality 2017, 29, 348-357. [CrossRef] [PubMed]

121. Liu, X.; Xu, X.; Li, C.; Zhang, H.; Fu, Q.; Shao, X.; Ye, Q.; Li, Z. Degradation of chiral neonicotinoid insecticide cycloxaprid in flooded and anoxic soil. Chemosphere 2015, 119, 334-341. [CrossRef] [PubMed]

122. Chen, M.; He, Y.; Yang, Y.; Huang, L.; Zhang, H.; Ye, Q.; Wang, H. Non-stereoselective transformation of the chiral insecticide cycloxaprid in aerobic soil. Sci. Total Environ. 2017, 579, 667-674. [CrossRef] [PubMed]

123. Cai, Z.; Wang, J.; Ma, J.; Zhu, X.; Cai, J.; Yang, G. Anaerobic degradation pathway of the novel chiral insecticide paichongding and its impact on bacterial communities in soils. J. Agric. Food Chem. 2015, 63, 7151-7160. [CrossRef] [PubMed]

124. Kurt-Karakus, P.B.; Stroud, J.L.; Bidleman, T.; Semple, K.T.; Jantunen, L.; Jones, K.C. Enantioselective degradation of organochlorine pesticides in background soils: Variability in field and laboratory studies. Environ. Sci. Technol. 2007, 41, 4965-4971. [CrossRef] [PubMed]

125. Sun, M.; Liu, D.; Zhou, G.; Li, J.; Qiu, X.; Zhou, Z.; Wang, P. Enantioselective degradation and chiral stability of malathion in environmental samples. J. Agric. Food Chem. 2011, 60, 372-379. [CrossRef] [PubMed]

126. Sun, D.; Pang, J.; Qiu, J.; Li, L.; Liu, C.; Jiao, B. Enantioselective degradation and enantiomerization of indoxacarb in soil. J. Agric. Food Chem. 2013, 61, 11273-11277. [CrossRef] [PubMed]

127. Cai, X.; Liu, W.; Sheng, G. Enantioselective degradation and ecotoxicity of the chiral herbicide diclofop in three freshwater alga cultures. J. Agric. Food Chem. 2008, 56, 2139-2146. [CrossRef] [PubMed]

128. Gu, X.; Wang, P.; Liu, D.; Lu, Y.; Zhou, Z. Stereoselective degradation of diclofop-methyl in soil and chinese cabbage. Pestic. Biochem. Physiol. 2008, 92, 1-7. [CrossRef]

129. Ma, Y.; Xu, C.; Wen, Y.; Liu, W. Enantioselective separation and degradation of the herbicide dichlorprop methyl in sediment. Chirality 2009, 21, 480-483. [CrossRef] [PubMed]

130. Qi, Y.; Liu, D.; Luo, M.; Jing, X.; Wang, P.; Zhou, Z. Enantioselective degradation and chiral stability of the herbicide fluazifop-butyl in soil and water. Chemosphere 2016, 146, 315-322. [CrossRef] [PubMed]

131. Frková, Z.; Johansen, A.; de Jonge, L.W.; Olsen, P.; Gosewinkel, U.; Bester, K. Degradation and enantiomeric fractionation of mecoprop in soil previously exposed to phenoxy acid herbicides-new insights for bioremediation. Sci. Total Environ. 2016, 569, 1457-1465. [CrossRef] [PubMed]

132. Li, Z.; Li, Q.; Cheng, F.; Zhang, W.; Wang, W.; Li, J. Enantioselectivity in degradation and transformation of quizalofop-ethyl in soils. Chirality 2012, 24, 552-557. [CrossRef] [PubMed]

133. Sukul, P.; Zühlke, S.; Lamshöft, M.; Rosales-Conrado, N.; Spiteller, M. Dissipation and metabolism of 14 c-spiroxamine in soil under laboratory condition. Environ. Pollut. 2010, 158, 1542-1550. [CrossRef] [PubMed]

134. Wang, X.; Jia, G.; Qiu, J.; Diao, J.; Zhu, W.; Lv, C.; Zhou, Z. Stereoselective degradation of fungicide benalaxyl in soils and cucumber plants. Chirality 2007, 19, 300-306. [CrossRef] [PubMed]

135. Gu, X.; Wang, P.; Liu, D.; Lv, C.; Lu, Y.; Zhou, Z. Stereoselective degradation of benalaxyl in tomato, tobacco, sugar beet, capsicum, and soil. Chirality 2008, 20, 125-129. [CrossRef] [PubMed]

136. Huang, L.; Lu, D.; Diao, J.; Zhou, Z. Enantioselective toxic effects and biodegradation of benalaxyl in scenedesmus obliquus. Chemosphere 2012, 87, 7-11. [CrossRef] [PubMed]

137. Sulimma, L.; Bullach, A.; Kusari, S.; Lamshöft, M.; Zühlke, S.; Spiteller, M. Enantioselective degradation of the chiral fungicides metalaxyl and furalaxyl by brevibacillus brevis. Chirality 2013, 25, 336-340. [CrossRef] [PubMed]

138. Chen, S.; Liu, W. Enantioselective degradation of metalaxyl in anaerobic activated sewage sludge. Bull. Environ. Contam. Toxicol. 2009, 82, 327-331. [CrossRef] [PubMed]

139. Jones, W.J.; Mazur, C.S.; Kenneke, J.F.; Garrison, A.W. Enantioselective microbial transformation of the phenylpyrazole insecticide fipronil in anoxic sediments. Environ. Sci. Technol. 2007, 41, 8301-8307. [CrossRef] [PubMed]

140. Tan, H.; Cao, Y.; Tang, T.; Qian, K.; Chen, W.L.; Li, J. Biodegradation and chiral stability of fipronil in aerobic and flooded paddy soils. Sci. Total Environ. 2008, 407, 428-437. [CrossRef] [PubMed] 
141. Qu, H.; Ma, R.X.; Liu, D.H.; Wang, P.; Huang, L.D.; Qiu, X.X.; Zhou, Z.Q. Enantioselective toxicity and degradation of the chiral insecticide fipronil in scenedesmus obliguus suspension system. Environ. Toxicol. Chem. 2014, 33, 2516-2521. [CrossRef] [PubMed]

142. Yao, G.; Jing, X.; Peng, W.; Liu, X.; Zhou, Z.; Liu, D. Chiral insecticide $\alpha$-cypermethrin and its metabolites: Stereoselective degradation behavior in soils and the toxicity to earthworm eisenia fetida. J. Agric. Food Chem. 2015, 63, 7714-7720. [CrossRef] [PubMed]

143. Yang, Z.H.; Ji, G.D. Enantioselective degradation mechanism of beta-cypermethrin in soil from the perspective of functional genes. Chirality 2015, 27, 929-935. [CrossRef] [PubMed]

144. Yang, Z.-H.; Ji, G.-D. Stereoselective degradation and molecular ecological mechanism of chiral pesticides beta-cypermethrin in soils with different ph values. Environ. Sci. Technol. 2015, 49, 14166-14175. [CrossRef] [PubMed]

145. Qin, S.; Budd, R.; Bondarenko, S.; Liu, W.; Gan, J. Enantioselective degradation and chiral stability of pyrethroids in soil and sediment. J. Agric. Food Chem. 2006, 54, 5040-5045. [CrossRef] [PubMed]

146. Li, Z.; Zhang, Z.; Zhang, L.; Leng, L. Isomer-and enantioselective degradation and chiral stability of fenpropathrin and fenvalerate in soils. Chemosphere 2009, 76, 509-516. [CrossRef] [PubMed]

147. Buerge, I.J.; Poiger, T.; Müller, M.D.; Buser, H.-R. Influence of ph on the stereoselective degradation of the fungicides epoxiconazole and cyproconazole in soils. Environ. Sci. Technol. 2006, 40, 5443-5450. [CrossRef] [PubMed]

148. Chu, B.L.; Guo, B.Y.; Peng, Z.; Wang, Z.; Guo, G.; Lin, J.M. Studies on degradation of imazalil enantiomers in soil using capillary electrophoresis. J. Sep. Sci. 2007, 30, 923-929. [CrossRef] [PubMed]

149. Zhang, Q.; Hua, X.; Yang, Y.; Yin, W.; Tian, M.; Shi, H.; Wang, M. Stereoselective degradation of flutriafol and tebuconazole in grape. Environ. Sci. Pollut. Res. 2015, 22, 4350-4358. [CrossRef] [PubMed]

150. Li, Z.; Zhang, Y.; Li, Q.; Wang, W.; Li, J. Enantioselective degradation, abiotic racemization, and chiral transformation of triadimefon in soils. Environ. Sci. Technol. 2011, 45, 2797-2803. [CrossRef] [PubMed]

151. Li, Z.; Li, Q.; Zhao, J.; Wang, W. Stereoselective degradation and microbial epimerization of triadimenol in soils. Chirality 2013, 25, 355-360. [CrossRef] [PubMed]

152. Wang, X.; Wang, X.; Zhang, H.; Wu, C.; Wang, X.; Xu, H.; Wang, X.; Li, Z. Enantioselective degradation of tebuconazole in cabbage, cucumber, and soils. Chirality 2012, 24, 104-111. [CrossRef] [PubMed]

153. Li, Y.; Dong, F.; Liu, X.; Xu, J.; Han, Y.; Zheng, Y. Enantioselectivity in tebuconazole and myclobutanil non-target toxicity and degradation in soils. Chemosphere 2015, 122, 145-153. [CrossRef] [PubMed]

154. Elsayed, O.F.; Maillard, E.; Vuilleumier, S.; Millet, M.; Imfeld, G. Degradation of chloroacetanilide herbicides and bacterial community composition in lab-scale wetlands. Sci. Total Environ. 2015, 520, 222-231. [CrossRef] [PubMed]

155. Zhang, Q.; Zhou, L.; Yang, Y.; Hua, X.; Shi, H.; Wang, M. Study on the stereoselective degradation of three triazole fungicides in sediment. Ecotoxicol. Environ. Saf. 2015, 117, 1-6. [CrossRef] [PubMed]

156. Zhang, Y.; Hu, D.; Meng, X.; Shi, Q.; Li, P.; Jin, L.; Zhang, K.; Song, B. Enantioselective degradation of indoxacarb from different commercial formulations applied to tea. Chirality 2015, 27, 262-267. [CrossRef] [PubMed]

157. Liu, D.; Wang, P.; Zhu, W.; Gu, X.; Zhou, W.; Zhou, Z. Enantioselective degradation of fipronil in chinese cabbage (brassica pekinensis). Food Chem. 2008, 110, 399-405. [CrossRef] [PubMed]

158. Dong, F.; Liu, X.; Zheng, Y.; Cao, Q.; Li, C. Stereoselective degradation of fungicide triadimenol in cucumber plants. Chirality 2010, 22, 292-298. [CrossRef] [PubMed]

159. Liang, H.; Qiu, J.; Li, L.; Li, W.; Zhou, Z.; Liu, F.; Qiu, L. Stereoselective dissipation of epoxiconazole in grape (vitis viniferacv. Kyoho) and soil under field conditions. Chemosphere 2012, 87, 982-987. [CrossRef] [PubMed]

160. Wang, M.; Zhang, Q.; Cong, L.; Yin, W.; Wang, M. Enantioselective degradation of metalaxyl in cucumber, cabbage, spinach and pakchoi. Chemosphere 2014, 95, 241-246. [CrossRef] [PubMed]

161. Qi, Y.; Liu, D.; Sun, M.; Di, S.; Wang, P.; Zhou, Z. The chiral separation and enantioselective degradation of the chiral herbicide napropamide. Chirality 2014, 26, 108-113. [CrossRef] [PubMed]

162. Chen, X.; Dong, F.; Xu, J.; Liu, X.; Wang, Y.; Zheng, Y. Enantioselective degradation of chiral insecticide dinotefuran in greenhouse cucumber and soil. Chirality 2015, 27, 137-141. [CrossRef] [PubMed]

163. Gu, X.; Lu, Y.; Wang, P.; Dang, Z.; Zhou, Z. Enantioselective degradation of diclofop-methyl in cole (brassica chinensis 1.). Food Chem. 2010, 121, 264-267. [CrossRef] 
164. Wang, M.; Hua, X.; Zhang, Q.; Yang, Y.; Shi, H.; Wang, M. Enantioselective degradation of metalaxyl in grape, tomato, and rice plants. Chirality 2015, 27, 109-114. [CrossRef] [PubMed]

165. Lv, T.; Zhang, Y.; Casas, M.E.; Carvalho, P.N.; Arias, C.A.; Bester, K.; Brix, H. Phytoremediation of imazalil and tebuconazole by four emergent wetland plant species in hydroponic medium. Chemosphere 2016, 148, 459-466. [CrossRef] [PubMed]

166. López-Cabeza, R.; Gámiz, B.; Cornejo, J.; Celis, R. Behavior of the enantiomers of the herbicide imazaquin in agricultural soils under different application regimes. Geoderma 2017, 293, 64-72. [CrossRef]

167. Lv, T.; Carvalho, P.N.; Casas, M.E.; Bollmann, U.E.; Arias, C.A.; Brix, H.; Bester, K. Enantioselective uptake, translocation and degradation of the chiral pesticides tebuconazole and imazalil by phragmites australis. Environ. Pollut. 2017, 229, 362-370. [CrossRef] [PubMed]

168. Schurig, V.; Reich, S. Determination of the rotational barriers of atropisomeric polychlorinated biphenyls (pcbs) by a novel stopped-flow multidimensional gas chromatographic technique. Chirality 1998, 10, 316-320. [CrossRef]

169. Vetter, W.; Schurig, V. Enantioselective determination of chiral organochlorine compounds in biota by gas chromatography on modified cyclodextrins. J. Chromatogr. A 1997, 774, 143-175. [CrossRef]

170. Vetter, W. Gas chromatographic enantiomer separation of polychlorinated biphenyls (pcbs): Methods, metabolisms, enantiomeric composition in environmental samples and their interpretation. Isr. J. Chem. 2016, 56, 940-957. [CrossRef]

171. Buerge, I.J.; Poiger, T.; Müller, M.D.; Buser, H.R. Enantioselective degradation of metalaxyl in soils: Chiral preference changes with soil ph. Environ. Sci. Technol. 2003, 37, 2668-2674. [CrossRef] [PubMed]

172. Kuivila, K.M.; Hladik, M.L.; Ingersoll, C.G.; Kemble, N.E.; Moran, P.W.; Calhoun, D.L.; Nowell, L.H.; Gilliom, R.J. Occurrence and potential sources of pyrethroid insecticides in stream sediments from seven U.S. Metropolitan areas. Environ. Sci. Technol. 2012, 46, 4297-4303. [CrossRef] [PubMed]

173. Ribeiro, A.R.; Carvalho, M.F.; Afonso, C.M.M.; Tiritan, M.E.; Castro, P.M. Microbial degradation of $17 \mathrm{beta}$ -estradiol and 17alpha -ethinylestradiol followed by a validated hplc-dad method. J. Environ. Sci. Health. Part. B, Pestic. Food Contam. Agric. Waste. 2010, 45, 265-273. [CrossRef] [PubMed]

174. Ribeiro, A.R.; Gonçalves, V.M.M.; Maia, A.S.; Carvalho, M.F.; Castro, P.M.; Tiritan, M.E. Microbial degradation of pharmaceuticals followed by a simple hplc-dad method. J. Environ. Sci. Health. Part A, Tox./Hazard. Subst. Environ. Eng. 2012, 47, 2151-2158. [CrossRef] [PubMed]

(C) 2017 by the authors. Licensee MDPI, Basel, Switzerland. This article is an open access article distributed under the terms and conditions of the Creative Commons Attribution (CC BY) license (http://creativecommons.org/licenses/by/4.0/). 